\title{
Antioxidant Capacity and Proanthocyanidin Composition of the Bark of Metasequoia glyptostroboides
}

\author{
Fengyang Chen, Lin Zhang, Shuling Zong, Shifang Xu, Xiaoyu Li, and Yiping Ye \\ Institute of Materia Medica, Zhejiang Academy of Medical Sciences, Tianmushan Road 182, Hangzhou, Zhejiang 310013, China \\ Correspondence should be addressed to Xiaoyu Li; 13355811895@189.cn and Yiping Ye; yeyiping2005@163.com
}

Received 29 October 2013; Accepted 15 February 2014; Published 17 March 2014

Academic Editor: Wen Chuan Lin

Copyright (c) 2014 Fengyang Chen et al. This is an open access article distributed under the Creative Commons Attribution License, which permits unrestricted use, distribution, and reproduction in any medium, provided the original work is properly cited.

\begin{abstract}
Metasequoia glyptostroboides Hu et Cheng is the only living species in the genus Metasequoia Miki ex Hu et Cheng (Taxodiaceae), which is well known as a "living fossil" species. In the Chinese folk medicine, the leaves and bark of M. glyptostroboides are used as antimicrobic, analgesic, and anti-inflammatory drug for dermatic diseases. This study is the first to report the free radical scavenging capacity, antioxidant activity, and proanthocyanidin composition of the bark of M. glyptostroboides. We observed total of six extracts and fractions, which were easily obtained by water-ethanol extraction and followed by a further separation with D101 resin column chromatography, had significant DPPH radical, superoxide anion radical, and hydroxyl radical scavenging capacity, total antioxidative capacity (T-AOC), lipid peroxidation inhibitory activity, and metal ions chelating capacity. The fraction MGEB, which was obtained by $60 \%$ ethanol extraction and followed by a further separation with D101 resin column chromatograph, possessed the highest proanthocyanidin content and the highest free radical scavenging and antioxidant activities. Furthermore, MGEB could significantly protect against $\mathrm{CCl}_{4}$ induced acute liver injury through inhibition of oxidative stress in mice. In addition, ten proanthocyanidins were isolated from MGEB, and six of them were firstly reported from this plant.
\end{abstract}

\section{Introduction}

Oxidation is essential to many organisms for the production of energy to fuel biological processes. However, reactive oxygen species (ROS) are often overproduced under pathological conditions, resulting in oxidative stress. The oxidative damage is a crucial etiological factor implicated in several chronic human diseases, such as diabetes mellitus, cancer, cardiovascular diseases, atherosclerosis, arthritis, and neurodegenerative diseases, as well as in degenerative processes associated with aging [1]. Therefore, the researches on antioxidants, especially exploration of potent natural compounds with low cytotoxicity from plants, have become an important branch of biomedicine [2].

The phenolic compounds, extensively distributed in different parts of the plant, have been proved to be natural antioxidants. The tree bark, which is easily available throughout the year and even the waste residues of some industrial production (such as paper production), is usually rich in phenolic compounds [3-7]. Up to now, the most prominent phenolic antioxidant from tree bark is Pycnogenol, which is commercially extracted from French maritime pine Pinus pinaster and mainly composed of proanthocyanidins (from $65 \%$ to $75 \%$ ). In view of its excellentfree radical scavenging capacity and antioxidant activity, Pycnogenol is now utilized throughout the world as a nutritional supplement and as a phytochemical remedy for various diseases ranging from chronic inflammation to circulatory dysfunction, including several impaired psychophysiological functions [8].

Metasequoia glyptostroboides $\mathrm{Hu}$ et Cheng (dawn redwood, Chinese redwood, or water fir in English and shui shan in Chinese) is the only living species in the genus Metasequoia Miki ex Hu et Cheng (Taxodiaceae), which is well known as a "living fossil" species. The discovery of the first living M. glyptostroboides in the south of China in the early 1940 s was one of the greatest botanical discoveries of the 20th century [9]. Now, it is mainly used as landscape tree and propagated in many parts of China and other countries. In the Chinese folk medicine, the leaves and bark of M. glyptostroboides are used as antimicrobic, analgesic, and anti-inflammatory drug for dermatic diseases. Thus far, the flavonoids, terpenoids, lignins, carotenoids, steroids, 
norlignans, and phenylpropanoids in the stems and leaves as well as essential oil in floral cones of M. glyptostroboides have been reported [10-14]. The total flavones extracts, essential oil, and some other chemical ingredients from this plant were proved to exhibit cardiovascular protective effect [15] and antibacterial, antioxidant, and cytotoxic activities [10, 11]. However, there is no report available in the literature on antioxidant properties of the bark of M. glyptostroboides and its active compounds. Hence, the present study was designed to evaluate the free radical scavenging capacity and antioxidant activity of the extracts from the bark of $M$. glyptostroboides and to isolate and identify the proanthocyanidin compounds in its active fractions.

\section{Materials and Methods}

2.1. Chemicals and Reagents. ${ }^{1} \mathrm{H}$ NMR, ${ }^{13} \mathrm{C}$ NMR, and DEPT spectra were recorded at $500 \mathrm{MHz}$ for ${ }^{1} \mathrm{H}$ and at $125 \mathrm{MHz}$ for ${ }^{13} \mathrm{C}$, with a Bruker DRX 500 instrument in DMSO- $d_{6}$ solution. ESI-MS spectra were recorded on a Bruker Esquire $3000^{\text {plus }}$ mass spectrometer, using a negative ion probe with samples dissolved in methanol.

1,1-Diphenyl-2-picrylhydrazyl (DPPH), ferrozine, and Folin-Ciocalteu reagent were purchased from Sigma Aldrich Co (St. Louis, MO, USA). The reference standard Pycnogenol (Maritime Pine Extract, containing $673 \mathrm{mg}$ proanthocyanidins per $g$ material) was purchased from the United States Pharmacopeial Convention (Rockville, MD, USA). The reference standards gallic acid (purity $\geq 98 \%$ ), rutin (purity $\geq$ 98\%), proanthocyanidins (purity $\geq 95 \%$ ), and ascorbic acid (purity $\geq 99 \%$ ) were purchased from Internet Aladdin reagent database Inc. (Shanghai, China). The detection kits for protein content, total antioxidative capacity (T-AOC), superoxide anion free radical, hydroxyl free radical and malondialdehyde (MDA), aspartate aminotransferase (AST), alanine aminotransferase (ALT), superoxide dismutase (SOD), and reduced glutathione (GSH) were purchased from Nanjing Jiancheng Bioengineering Institute (Nanjing, Jiangsu, China). All other reagents were of analytical grade and made in China.

2.2. Plant Material. The barks of M. glyptostroboides were collected in the Hangzhou Xiaoshan, Zhejiang Province, China, in May 2010, and were identified according to the Flora of China by one of the authors (Dr. Xiaoyu Li). A voucher specimen (number 20100505) has been deposited at the Laboratory of Nature Drug, Institute of Materia Medica, Zhejiang Academy of Medical Sciences, China. The plant materials were dried under shade, pulverized, and stored at $4^{\circ} \mathrm{C}$ for further use.

2.3. Preparation of the Extracts and Fractions. The extracts and fractions were prepared from the barks of $M$. glyptostroboides under subdued light by water-ethanol extraction and D101 resin column chromatography. In detail, the pulverized bark of M. glyptostroboides $(1.0 \mathrm{~kg}$ ) was extracted three times with water, $60 \%$ or $95 \%$ ethanol under reflux for $2 \mathrm{~h}$, respectively. The extract was filtered through Whatman filter paper. The filtrate was concentrated in a rotary evaporator under reduced pressure and then lyophilized to obtain water, $60 \%$ ethanol, and 95\% ethanol extract, named as MGW (69 g), MGE60 (101 g), and MGE95 (70 g), respectively. The MGE60 (50 g) was then subjected to D101 resin column chromatography and eluted subsequently with water and $30 \%$ and $50 \%$ ethanol. Finally, the eluates were concentrated and lyophilized to yield water (MGEA, $7 \mathrm{~g}$ ) and 30\% (MGEB, $17 \mathrm{~g}$ ) and $50 \%$ ethanol (MGEC, $2 \mathrm{~g}$ ) fractions. All the extracts and fractions were stored at $4^{\circ} \mathrm{C}$ for subsequent analyses.

2.4. Isolation and Identification of Proanthocyanidins. The brown powder MGEB (100 g) prepared as the above method was subjected to Sephadex LH-20 column chromatography $\left(\mathrm{EtOH} / \mathrm{H}_{2} \mathrm{O} 4: 6 \rightarrow 95: 5 \mathrm{v} / \mathrm{v}\right.$, then acetone $/ \mathrm{H}_{2} \mathrm{O} 2: 8 \rightarrow$ $6: 4 \mathrm{v} / \mathrm{v})$. The fraction eluted with $\mathrm{EtOH} / \mathrm{H}_{2} \mathrm{O}(8: 2, \mathrm{v} / \mathrm{v})$ was separated by HPLC $\left(\mathrm{MeOH} / \mathrm{H}_{2} \mathrm{O}\right)$ to give $\mathbf{1}(435 \mathrm{mg})$, $2(13 \mathrm{mg}), 3(24 \mathrm{mg})$, and $4(29 \mathrm{mg})$. The fractions eluted with $\mathrm{EtOH} / \mathrm{H}_{2} \mathrm{O}(95: 5, \mathrm{v} / \mathrm{v})$ and acetone $/ \mathrm{H}_{2} \mathrm{O}(2: 8, \mathrm{v} / \mathrm{v})$ were separated by HPLC (Agilent 1100 HPLC, column: Zorbax 300SB-C18 PrepHT, $21.2 \times 250 \mathrm{~mm}, 7 \mu \mathrm{m}$; mobile phase: $\mathrm{MeOH}: \mathrm{H}_{2} \mathrm{O}=65: 35$; flow rate: $8 \mathrm{~mL} / \mathrm{min}$ ) to give 5 (107 mg), 6 (16 mg), 7 (18 mg), 8 (89 mg), 9 (18 mg), and 10 (47 mg). All the compounds were identified by NMR and MS spectroscopy and by comparison with spectral literature data [16-22].

2.5. Total Phenolic, Flavonoid, and Proanthocyanidin Content Determination. The total phenolic and flavonoid contents of the sample were determined by the methods described in the Chinese Pharmacopoeia (Chinese Pharmacopoeia Committee, 2010). The total phenolic content was analyzed based on Folin-Ciocalteu colourimetric method, using gallic acid as a standard. The sample was dissolved in distilled water and diluted appropriately and then mixed with $1 \mathrm{~mL}$ FolinCiocalteu solution. The mixture was adjusted to $25 \mathrm{~mL}$ with $29 \%$ sodium carbonate and allowed to rest for $30 \mathrm{~min}$ in the dark. The absorbance $(A)$ was measured at $760 \mathrm{~nm}$, and the total phenolic content was expressed as gallic acid equivalents (mg GAE/g sample).

To determine the total flavonoid content, the sample was dissolved in 50\% ethanol and mixed with $1 \mathrm{~mL} \mathrm{NaNO}_{2}$ (5\%). After standing for $6 \mathrm{~min}, 1 \mathrm{~mL}$ of $10 \% \mathrm{AlCl}_{3}$ and $10 \mathrm{~mL}$ of $\mathrm{NaOH}(1.075 \mathrm{M})$ were added to the mixture. The mixture was adjusted to $25 \mathrm{~mL}$ with $50 \%$ ethanol and allowed to rest for $15 \mathrm{~min}$. The absorbance $(A)$ was measured at $510 \mathrm{~nm}$. Rutin was used as a reference standard and the total flavonoid content was expressed as rutin equivalents (mg RE/g sample).

The total proanthocyanidin content of the sample was determined by the $n$-Butanol/HCl assay [23]. The sample was dissolved in methanol and diluted appropriately. $1 \mathrm{~mL}$ of sample solution was added to $6 \mathrm{~mL}$ of a $95 \%$ solution of $n$ Butanol/HCl $(95: 5 \mathrm{v} / \mathrm{v})$ in stoppered test tubes followed by $0.25 \mathrm{~mL}$ of a solution of $\mathrm{NH}_{4} \mathrm{Fe}\left(\mathrm{SO}_{4}\right)_{2} \cdot 12 \mathrm{H}_{2} \mathrm{O}$ in $2 \mathrm{M} \mathrm{HCl}$. The tubes were incubated for $40 \mathrm{~min}$ at $95^{\circ} \mathrm{C}$. After being cooled in the dark, the absorbance $(A)$ was measured at $550 \mathrm{~nm}$. Proanthocyanidin standard was used as a reference and the total proanthocyanidin content was expressed as 
proanthocyanidin equivalents (mg PE/g sample). All these three content determinations were performed in triplicate.

2.6. Free Radical Scavenging Activity Determination. The DPPH radical scavenging activities were determined according to the method described by Yokozawa et al. [24] with some modification. Briefly, in 96-well flat-bottom plates, $100 \mu \mathrm{L}$ of $0.5 \mathrm{mM}$ freshly prepared DPPH ethanol solution was added to $100 \mu \mathrm{L}$ of sample solution in $50 \%$ ethanol at different concentrations. The mixture was shaken vigorously and incubated for $30 \mathrm{~min}$ in the dark at room temperature. The absorbance of each reaction mixture was measured at $517 \mathrm{~nm}$. Lower absorbance of the reaction mixture indicated higher free radical scavenging activity.

The scavenging effect on superoxide anion radical and hydroxyl radical were estimated using assay kits according to the manufacturer's instructions [25]. The superoxide anion radical and hydroxyl radical were generated by PMS-NADH system and Fenton reaction, respectively. The quantity of radical in system is determined using Griess reagent colorimetric method. Following manufactures instructions the reaction was conducted at $37^{\circ} \mathrm{C}$ in a water bath and the absorbance determined at $550 \mathrm{~nm}$ with the blank comprising reagents only.

For these three free radical scavenging assays, all the tests were performed in triplicate. Ascorbic acid was used as a standard and the antioxidant capacity was calculated as gram ascorbic acid equivalents per gram sample ( $\mathrm{g}$ ascorbic acid eq./g).

2.7. Antioxidant Activity Determination. T-AOC was measured by ferric reducing antioxidant power assay (FRAP) [26] using assay kits according to the manufacturer's instructions. The tests were performed in triplicate. Ascorbic acid was used as a standard and the antioxidant capacity was calculated as gram ascorbic acid equivalents per gram sample (g ascorbic acid eq./g).

The lipid peroxidation inhibitory activity and ferrous ion $\left(\mathrm{Fe}^{2+}\right)$ chelating activity were determined by the methods as our previously used [2]. Lipid peroxidation was induced by $\mathrm{FeCl}_{2}$-ascorbic acid in rat liver tissues. The level of lipid peroxidation was indicated by the amount of MDA assayed using detection kits by the thiobarbituric acid reaction (TBARS). Ferrous ion $\left(\mathrm{Fe}^{2+}\right)$ chelating activity was indicated by inhibition of the formation of $\mathrm{Fe}^{2+}$-ferrozine complex. The rate of inhibition and half inhibitory concentration $\left(\mathrm{IC}_{50}\right)$ value were calculated with the NDST software. Each test was performed in triplicate.

2.8. In Vivo Antioxidant Activity Determination. Six-weekold male ICR mice were purchased from Zhejiang Experimental Animal Center (Certificate number SCXK 2008-0033, Hangzhou, Zhejiang, China). Rodent laboratory chow and tap water were provided ad libitum and maintained under controlled conditions: temperature $24 \pm 1^{\circ} \mathrm{C}$, humidity $50 \pm$ $10 \%, 12 \mathrm{~h}$ light $/ 12 \mathrm{~h}$ dark cycle. All the procedures were in strict accordance with Chinas legislation on the use and care of laboratory animals and with the guidelines established by the Institute for Experimental Animals and were approved by the Committee for Animal Experiments.

The animals were randomly divided into five groups, each consisting of ten mice. The five groups are the normal group, the model control group, the two test groups, and the positive control group. Mice in the two test groups and the positive control group were treated with MGEB at a dose of $20,80 \mathrm{mg} / \mathrm{kg}$, or silymarin at a dose of $20 \mathrm{mg} / \mathrm{kg}$ body weight for seven consecutive days (p.o., once per day), while mice in normal group and model group were treated with physiological saline. The mice were injected with $\mathrm{CCl}_{4}$ $\left(10 \mathrm{~mL} / \mathrm{kg}\right.$ i.p. of $0.125 \% \mathrm{CCl}_{4}$ solution in olive oil) one hour after the sixth administration, except for the normal group, which was given only olive oil injection. The animals were sacrificed $24 \mathrm{~h}$ after the $\mathrm{CCl}_{4}$ treatment. Serum was collected for ALT and AST determination. Liver was collected for SOD, MDA, T-AOC, and GSH investigations and histopathologic analysis.

The activities of ALT, AST, SOD, MDA, T-AOC, and GSH were determined by assay kits according to the manufacturer's instructions. Pieces of liver tissues were stained with hematoxylin-eosin (HE) and examined under light microscope (Olympus, Japan) for general histopathology examination.

2.9. Statistical Analysis. The data were expressed as mean \pm standard deviation (SD) and examined for their statistical significance of difference with ANOVA and the Standard's $t$-test. $P$ values of less than 0.05 were considered to be statistically significant. Correlation analysis were carried out using the correlation and regression program in Microsoft Office Excel to study the relationship between free radical scavenging, antioxidant activities, and total phenolic, flavonoid, and proanthocyanidin content.

\section{Results}

3.1. Total Phenolic, Flavonoid, and Proanthocyanidin Contents. The contents of total phenolics, flavonoids, and proanthocyanidins in each extract and fraction were determined by Folin-Ciocalteu colourimetric, aluminium colourimetric, and $n$-Butanol/HCl method, respectively. As shown in Table 1, among three extracts, the $95 \%$ ethanol extract (MGE95) had the highest contents of total phenolics and proanthocyanidins. The total phenolic, flavonoid, and proanthocyanidin contents in MGEB, obtained by $60 \%$ ethanol extraction and 30\% ethanol elution with D101 resin column chromatograph, were significantly higher than those of crude extracts and other two fractions. Meanwhile, the yield of MGEB was also higher than that of other two fractions. Furthermore, MGEB are close to Pycnogenol in the total proanthocyanidin contents, being $627.5 \pm 8.7 \mathrm{mg} \mathrm{PE} / \mathrm{g}$ and $650-750 \mathrm{mg} \mathrm{PE} / \mathrm{g}$, respectively.

3.2. Free Radical Scavenging Capacity. All the extracts and fractions dose dependently showed DPPH, superoxide anion, and hydroxyl radical scavenging capacities at the concentrations of $2 \sim 200 \mu \mathrm{g} / \mathrm{mL}$ (data no shown). As shown in 
TABLE 1: The contents of total phenolic, flavonoid, and proanthocyanidin in the extracts and fractions from the bark of M. glyptostroboides.

\begin{tabular}{lcccc}
\hline Samples & Yield of extract (\%) & Total phenolics $(\mathrm{mg} \mathrm{GAE} / \mathrm{g})$ & Total flavonoids $(\mathrm{mg}$ RE/g) & Total proanthocyanidins (mg PE/g) \\
\hline MGW & 6.9 & $184.8 \pm 0.4^{\mathrm{e}}$ & $317.3 \pm 2.8^{\mathrm{e}}$ & $26.8 \pm 1.6^{\mathrm{e}}$ \\
MGE60 & 10.1 & $305.2 \pm 1.3^{\mathrm{c}}$ & $433.5 \pm 2.8^{\mathrm{b}}$ & $348.9 \pm 2.6^{\mathrm{c}}$ \\
MGE95 & 7.0 & $384.6 \pm 0.5^{\mathrm{b}}$ & $356.7 \pm 2.8^{\mathrm{c}}$ & $404.6 \pm 12.6^{\mathrm{b}}$ \\
MGEA & 1.4 & $50.2 \pm 3.1^{\mathrm{f}}$ & $40.6 \pm 4.2^{\mathrm{f}}$ & $1.5 \pm 0.1^{\mathrm{f}}$ \\
MGEB & 3.4 & $716.7 \pm 8.2^{\mathrm{a}}$ & $823.4 \pm 5.6^{\mathrm{a}}$ & $627.5 \pm 8.7^{\mathrm{a}}$ \\
MGEC & 0.4 & $274.4 \pm 0.6^{\mathrm{d}}$ & $339.0 \pm 2.8^{\mathrm{d}}$ & $56.3 \pm 1.1^{\mathrm{d}}$ \\
\hline
\end{tabular}

Values of contents are mean \pm standard deviation of three replicate analyses. Means with different letters (a-f) within the same column differed significantly $(P<0.05)$ and are arranged in the following contents descending order: $\mathrm{a}>\mathrm{b}>\mathrm{c}>\mathrm{d}>\mathrm{e}>\mathrm{f}$.

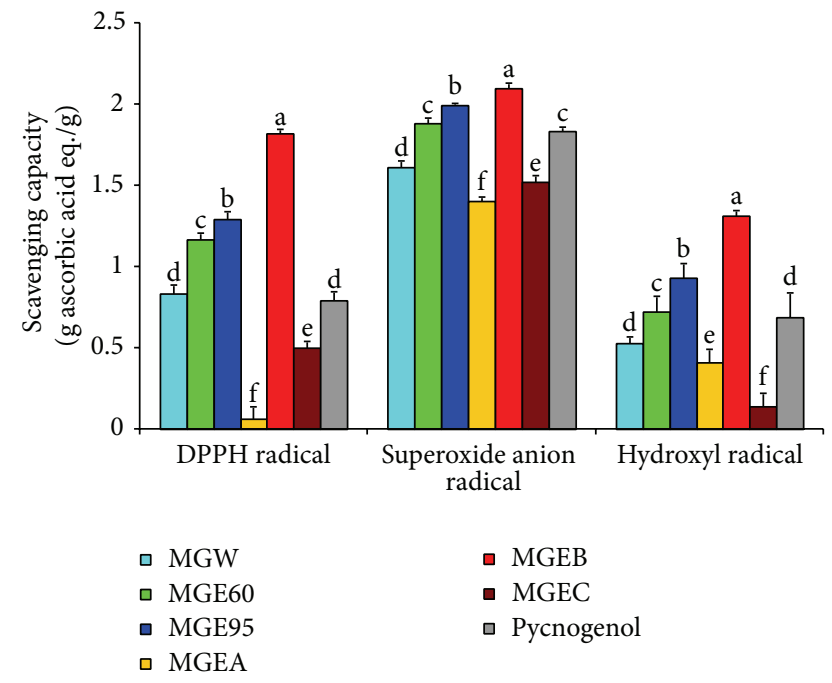

FIGURE 1: Free radical scavenging capacity of the extracts and fractions from the bark of M. glyptostroboides. Values are mean \pm standard deviation of three replicate analyses. Means with different letters $(\mathrm{a}-\mathrm{f})$ within the same column differed significantly $(P<0.05)$ and are arranged in the following scavenging capacity descending order: $a>b>c>d>e>f$.

Figure 1, the DPPH radical scavenging capacity was arranged in the following descending order: MGEB > MGE95 > MGE60 > MGW > MGEC > MGEA $(P<0.05)$. Among them, MGEB, MGE95, MGE60, and MGW showed higher scavenging capacity than Pycnogenol. Moreover, the DPPH radical scavenging capacity of MGEB, MGE95, and MGE60 were higher than that of ascorbic acid (values $>1$ ).

MGEB also possessed the strongest superoxide anion and hydroxyl radical scavenging capacity. Moreover, the arrangement order of superoxide anion radical scavenging capacity of extracts and fractions is consistent with the findings in DPPH radical scavenging capacity. All of the samples including Pycnogenol showed higher superoxide anion radical scavenging capacity than that of ascorbic acid (values > 1), while only MGEB showed higher hydroxyl radical scavenging capacity than that of ascorbic acid. We also found that both superoxide anion radical and hydroxyl radical scavenging capacities of MGEB and MGE95 were higher than that of Pycnogenol $(P<0.05)$.
3.3. Antioxidant Activity. T-AOC of the extracts and fractions from the bark of $M$. glyptostroboides were measured by FRAP assay [26]. As shown in Figure 2(a), the T-AOC was arranged in the following descending order: MGEB > MGE95 > MGE60 > MGEW > MGEC > MGEA $(P<0.05)$. Though the T-AOC of the extracts and fraction samples were not higher than that of ascorbic acid (values < 1), MGEB and MGE95 showed higher antioxidant activities than Pycnogenol $(P<$ 0.05).

The lipid peroxidation inhibitory activity was shown in Figure 2(b). All the extracts and fractions exhibited significant lipid peroxidation inhibitory activities. Moreover, MGEB, MGE95, and MGE60 showed higher activities than Pycnogenol $(P<0.05)$.

All the extracts and fractions exhibited moderate $\mathrm{Fe}^{2+}$ chelating activities (Figure 2(b)). The $\mathrm{IC}_{50}$ values of these extracts were higher than those of the positive standard EDTA $\left(\mathrm{IC}_{50}: 4.24 \pm 0.08 \mu \mathrm{g} / \mathrm{mL}\right)$, but lower than those of Pycnogenol $(P<0.05)$. Being consistent with the findings above, MGEB possessed the strongest $\mathrm{Fe}^{2+}$ chelating activity.

3.4. Relationship between Free Radical Scavenging, Antioxidant Activities, and the Content of Total Phenolics, Flavonoids, and Proanthocyanidins. The relationship between free radical scavenging, antioxidant activities, and the content of total phenolics, flavonoids, and proanthocyanidins was further analyzed by the correlation and regression program, and the results were shown in Table 2 . The correlation coefficient $(R)$ between the total contents and the free radical scavenging activities or total antioxidant capacity was found to be significant. However, the poor correlation coefficient was observed between the total contents and the lipid peroxidation inhibitory activity or $\mathrm{Fe}^{2+}$ chelating activity. These results were similar to the studies conducted by Liu et al. [27] in emblica fruit. In addition, the correlation coefficient between the total proanthocyanidin contents and the free radical scavenging or antioxidant activities was shown to be most significant for all the cases, especially in hydroxyl radical and superoxide anion radical.

3.5. In Vivo Antioxidant Activity of $M G E B$. The in vivo antioxidant activity of MGEB was evaluated for $\mathrm{CCl}_{4}$ induced acute liver injury in mice. $\mathrm{CCl}_{4}$ administration at day 6 resulted in a slight decrease of body weight (Figure 3(b)) 


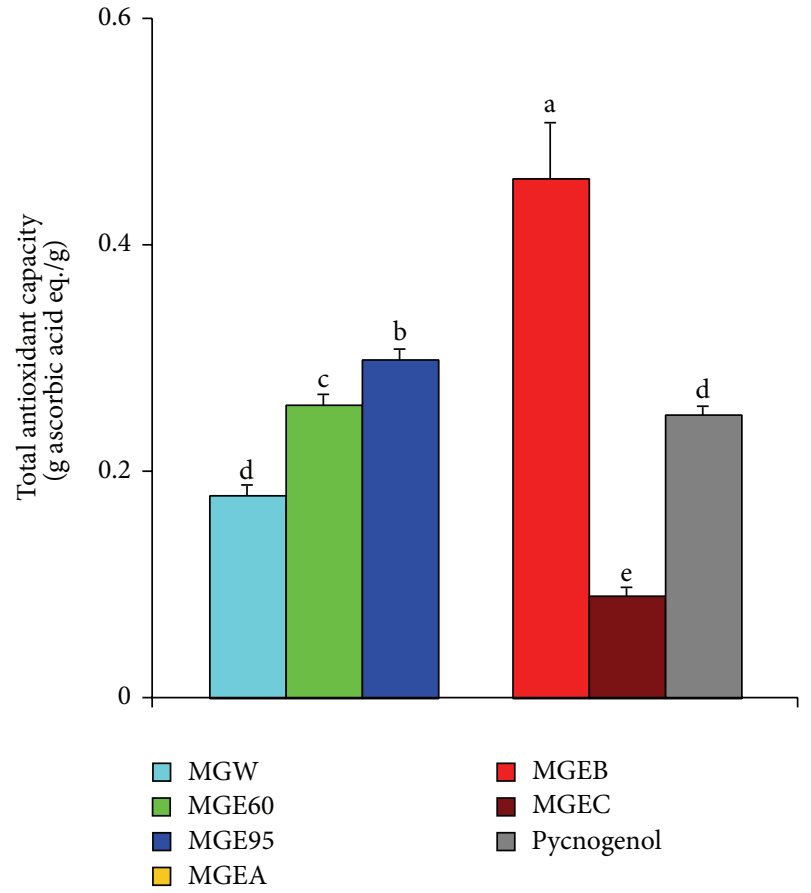

(a)

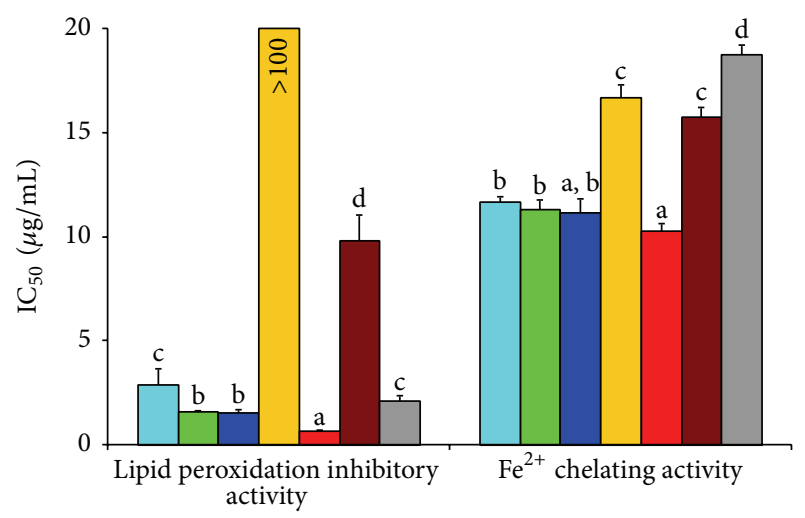

(b)

FIGURE 2: Antioxidant activity of the extracts and fractions from the bark of M. glyptostroboides. Values are mean \pm standard deviation of three replicate analyses. Means with different letters $(a-f)$ within the same column differed significantly $(P<0.05)$ and are arranged in the following antioxidant activity descending order: $a>b>c>d>$ e $>$ f.

and significant elevation of serum AST and ALT activity (Figure 3(a)). Histopathological examination of livers challenged with $\mathrm{CCl}_{4}$ showed vacuole formation, inflammatory infiltration, and widespread necrotic cells (Figure 3(c)). $\mathrm{CCl}_{4}$ also significantly induced oxidative stress in the liver (Figure 4). $\mathrm{CCl}_{4}$ caused a significant increase of MDA level and decrease of T-AOC, SOD, and GSH levels in the liver. Oral administration of MGEB at the doses of $20,80 \mathrm{mg} / \mathrm{kg}$ or silymarin at the dose of $20 \mathrm{mg} / \mathrm{kg}$ body weight prior to $\mathrm{CCl}_{4}$ treatment significantly restored the activities of AST and ALT. The histological observations basically supported these results. MGEB and silymarin were able to prevent the development of histopathological changes, which exhibited areas of normal liver architecture and patches of inflammatory infiltration and necrotic hepatocytes. In addition, MGEB and silymarin significantly reversed the $\mathrm{CCl}_{4}$ induced MDA elevation and T-AOC, SOD, and GSH descent. Moreover, no signs of toxicity were observed in the MGEB-treated mice on the basis of body weight and microscopic examination of individual organs. These findings indicated that MGEB could significantly protect against $\mathrm{CCl}_{4}$ induced acute liver injury through inhibition of lipid peroxidation and the increase of antioxidant activity.

3.6. Structural Elucidation of Proanthocyanidin Composition from $M G E B$. Ten proanthocyanidins were isolated and identified from MGEB; the structure elucidations of them were identified by spectral techniques as ES-MS, ${ }^{1} \mathrm{H}$ and ${ }^{13} \mathrm{C}$ NMR (Figure 5). Previous phytochemical investigations have reported the presence of compounds 1-4 from the branches and stems of M. glyptostroboides [14]. Compounds 5-10 are reported for the first time from this plant.

3.6.1. Catechin (1). ESI-MS gave an $[\mathrm{M}-\mathrm{H}]^{-}$at $m / z: 289 .{ }^{1} \mathrm{H}$ NMR $\left(500 \mathrm{MHz}, \mathrm{DMSO}-d_{6}\right): \delta 6.73\left(1 \mathrm{H}, \mathrm{d}, J=2.0 \mathrm{~Hz}, \mathrm{H}-2^{\prime}\right)$, $6.70\left(1 \mathrm{H}, \mathrm{d}, J=8.0 \mathrm{~Hz}, \mathrm{H}-6^{\prime}\right), 6.61(1 \mathrm{H}, \mathrm{dd}, J=2.0,8.0 \mathrm{~Hz}$, H-5 $\left.{ }^{\prime}\right), 5.90(1 \mathrm{H}, \mathrm{d}, J=2.0 \mathrm{~Hz}, \mathrm{H}-8), 5.69(1 \mathrm{H}, \mathrm{d}, J=2.0 \mathrm{~Hz}, \mathrm{H}-$ 6), $4.49(1 \mathrm{H}, \mathrm{d}, J=7.5 \mathrm{~Hz}, \mathrm{H}-2), 3.82(1 \mathrm{H}, \mathrm{m}, \mathrm{H}-3), 2.64(1 \mathrm{H}$, $\mathrm{m}, \mathrm{H}-4 \alpha), 2.33(1 \mathrm{H}, \mathrm{m}, \mathrm{H}-4 \beta) .{ }^{13} \mathrm{C}$ NMR $(125 \mathrm{MHz}, \mathrm{DMSO}-$ $\left.d_{6}\right): \delta 156.40$ (C-7), $156.15(\mathrm{C}-5), 155.34$ (C-8a), $144.82\left(\mathrm{C}-3^{\prime}\right.$, $\left.4^{\prime}\right), 130.58\left({\mathrm{C}-1^{\prime}}^{\prime}\right), 118.41\left(\mathrm{C}-6^{\prime}\right), 115.04\left(\mathrm{C}-5^{\prime}\right), 114.49\left(\mathrm{C}-2^{\prime}\right)$, 99.04 (C-4a), 95.05 (C-6), 93.79 (C-8), 80.98 (C-2), 66.28 (C3), 27.86 (C-4).

3.6.2. Epicatechin (2). ESI-MS gave an $[\mathrm{M}-\mathrm{H}]^{-}$at $m / z: 289$. ${ }^{1} \mathrm{H}$ NMR $\left(500 \mathrm{MHz}, \mathrm{DMSO}-d_{6}\right): \delta 6.89\left(1 \mathrm{H}\right.$, br s, H-2 $\left.{ }^{\prime}\right), 6.68$ $\left(1 \mathrm{H}, \mathrm{d}, J=8.5 \mathrm{~Hz}, \mathrm{H}-6^{\prime}\right), 6.66\left(1 \mathrm{H}, \mathrm{d}, J=8.5 \mathrm{~Hz}, \mathrm{H}-5^{\prime}\right), 5.89$ $(1 \mathrm{H}, \mathrm{d}, J=1.5 \mathrm{~Hz}, \mathrm{H}-6), 5.72(1 \mathrm{H}, \mathrm{d}, J=2.0 \mathrm{~Hz}, \mathrm{H}-8), 4.73(1 \mathrm{H}$, s, H-2), $4.00(1 \mathrm{H}, \mathrm{d}, J=2.5 \mathrm{~Hz}, \mathrm{H}-3), 2.70(1 \mathrm{H}, \mathrm{dd}, J=4.5$, $16.5 \mathrm{~Hz}, \mathrm{H}-4 \alpha), 2.46(1 \mathrm{H}, \mathrm{dd}, J=3.0,16.5 \mathrm{~Hz}, \mathrm{H}-4 \beta) .{ }^{13} \mathrm{C} \mathrm{NMR}$ $\left(125 \mathrm{MHz}, \mathrm{DMSO}-d_{6}\right): \delta 156.48(\mathrm{C}-7), 156.20(\mathrm{C}-5), 155.73(\mathrm{C}-$ 8a), $144.46\left(\mathrm{C}-4^{\prime}\right), 144.40\left(\mathrm{C}-3^{\prime}\right), 130.58\left(\mathrm{C}-1^{\prime}\right), 117.92\left(\mathrm{C}-6^{\prime}\right)$, $114.87\left(\mathrm{C}-5^{\prime}\right), 114.73\left(\mathrm{C}-2^{\prime}\right), 98.48$ (C-4a), 95.06 (C-6), 94.07 (C-8), 78.02 (C-2), 64.88 (C-3), 28.14 (C-4).

3.6.3. Gallocatechin (3). ESI-MS gave an $[\mathrm{M}-\mathrm{H}]^{-}$at $m / z: 305$. ${ }^{1} \mathrm{H}$ NMR (500 MHz, DMSO- $\left.d_{6}\right): \delta 6.25\left(2 \mathrm{H}, \mathrm{s}, \mathrm{H}-2^{\prime}, 6^{\prime}\right), 5.88$ $(1 \mathrm{H}, \mathrm{d}, J=2.0 \mathrm{~Hz}, \mathrm{H}-8), 5.69(1 \mathrm{H}, \mathrm{d}, J=2.0 \mathrm{~Hz}, \mathrm{H}-6), 4.44(1 \mathrm{H}$, $\left.\mathrm{d}, J=7.0 \mathrm{~Hz}, \mathrm{H}-2^{\prime}\right), 3.80(1 \mathrm{H}, \mathrm{m}, \mathrm{H}-3), 2.63(1 \mathrm{H}, \mathrm{dd}, J=5.5$, $16.5 \mathrm{~Hz}, \mathrm{H}-4 \alpha), 2.37(1 \mathrm{H}, \mathrm{dd}, J=7.5,16.5 \mathrm{~Hz}, \mathrm{H}-4 \beta) .{ }^{13} \mathrm{C} \mathrm{NMR}$ $\left(125 \mathrm{MHz}, \mathrm{DMSO}-d_{6}\right): \delta 156.36(\mathrm{C}-7), 156.11(\mathrm{C}-5), 155.23(\mathrm{C}-$ 8a), $145.57\left(\mathrm{C}-3^{\prime}, 5^{\prime}\right), 132.44\left(\mathrm{C}-4^{\prime}\right), 129.8\left(\mathrm{C}-1^{\prime}\right), 105.95\left(\mathrm{C}-2^{\prime}\right.$, $\left.6^{\prime}\right), 98.95$ (C-4a), 95.05 (C-6), 93.82 (C-8), 80.98 (C-2), 66.25 (C-3), 27.33 (C-4).

3.6.4. Epigallocatechin (4). ESI-MS gave an $[\mathrm{M}-\mathrm{H}]^{-}$at $m / z$ : 305. ${ }^{1} \mathrm{H}$ NMR $\left(500 \mathrm{MHz}, \mathrm{DMSO}-d_{6}\right): \delta 6.37\left(2 \mathrm{H}, \mathrm{s}, \mathrm{H}-2^{\prime}, 6^{\prime}\right)$, $5.89(1 \mathrm{H}, \mathrm{d}, J=2.0 \mathrm{~Hz}, \mathrm{H}-8), 5.71(1 \mathrm{H}, \mathrm{d}, J=2.0 \mathrm{~Hz}, \mathrm{H}-6)$, $4.66(1 \mathrm{H}, \mathrm{s}, \mathrm{H}-2), 4.13(1 \mathrm{H}, \mathrm{m}, \mathrm{H}-3), 2.69$ (1H, dd, $J=4.5$, 
TABLE 2: Relationship between free radical scavenging, antioxidant activities, and the content of total phenolic, flavonoid, and proanthocyanidin of the extracts and fractions from the bark of M. glyptostroboides.

\begin{tabular}{lccc}
\hline & & $R$ & \\
& Total phenolics & Total flavonoids & Total proanthocyanidins \\
\hline DPPH radical scavenging capacity & 0.9127 & 0.9114 & 0.9311 \\
Hydroxyl radical scavenging capacity & 0.8244 & 0.7679 & 0.9242 \\
Superoxide anion radical scavenging capacity & 0.8710 & 0.8251 & 0.9626 \\
Total antioxidant capacity & 0.9319 & 0.9215 & 0.9430 \\
Lipid peroxidation inhibitory activity & 0.4521 & 0.4665 & 0.6941 \\
Fe $^{2+}$ chelating activity & 0.6932 & 0.7387 & 0.7662 \\
\hline
\end{tabular}

The contents of total phenolics, flavonoids, and proanthocyanidins were expressed as gallic acid equivalents (mg GAE/g sample), rutin equivalents (mg RE/g sample), and proanthocyanidin equivalents (mg PE/g sample). The DPPH, hydroxyl, superoxide anion radical scavenging capacity and total antioxidant capacity were calculated as gram ascorbic acid equivalents per gram sample (g ascorbic acid eq./g). The lipid peroxidation inhibitory activity and Fe ${ }^{2+}$ chelating activity were calculated as half inhibitory concentration $\left(\mathrm{IC}_{50}\right)$ value. Each regression line and correlation coefficient $(R)$ were analyzed by the correlation and regression program in Microsoft Office Excel.

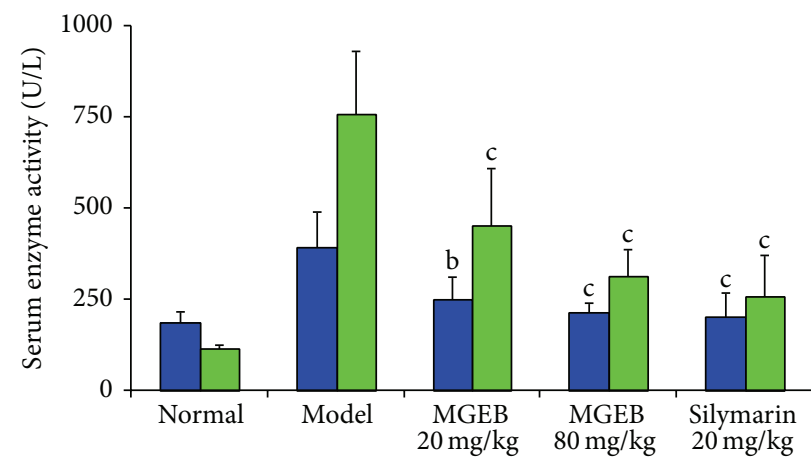

$\square$ AST

$\square$ ALT

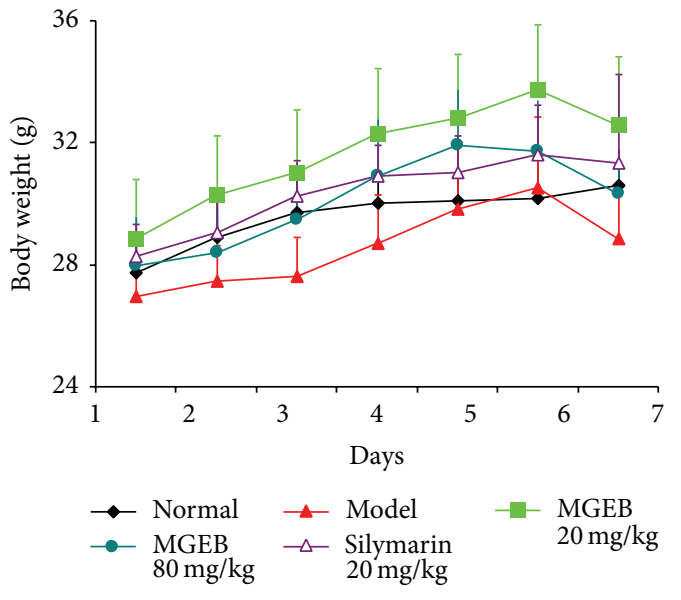

(b)
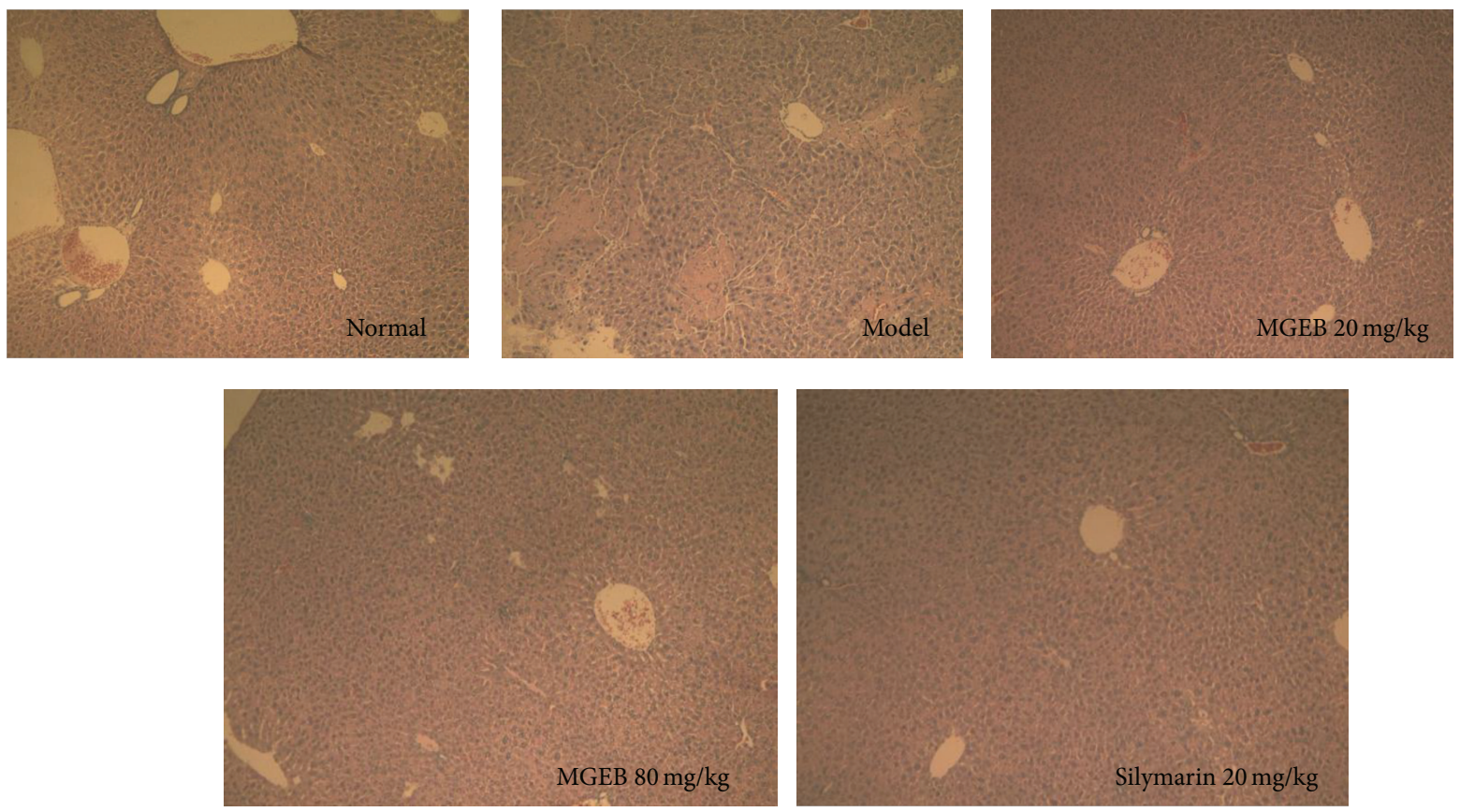

(c)

FIGURE 3: MGEB protect against $\mathrm{CCl}_{4}$ induced acute liver injury of mice. (a) Serum hepatic enzyme activity of ALT and AST. The data were expressed as mean \pm standard deviation $(n=10)$; significant differences with model group were designated as ${ }^{\mathrm{b}} P<0.01$, ${ }^{\mathrm{c}} P<0.001$. $(\mathrm{b})$ Body weights of the mice were measured every day. Data represent the mean \pm standard deviation $(n=10)$. (c) Slices of liver were stained with hematoxylin and eosin for histopathological analysis. Representative histomicrographs of liver sections of each group. 

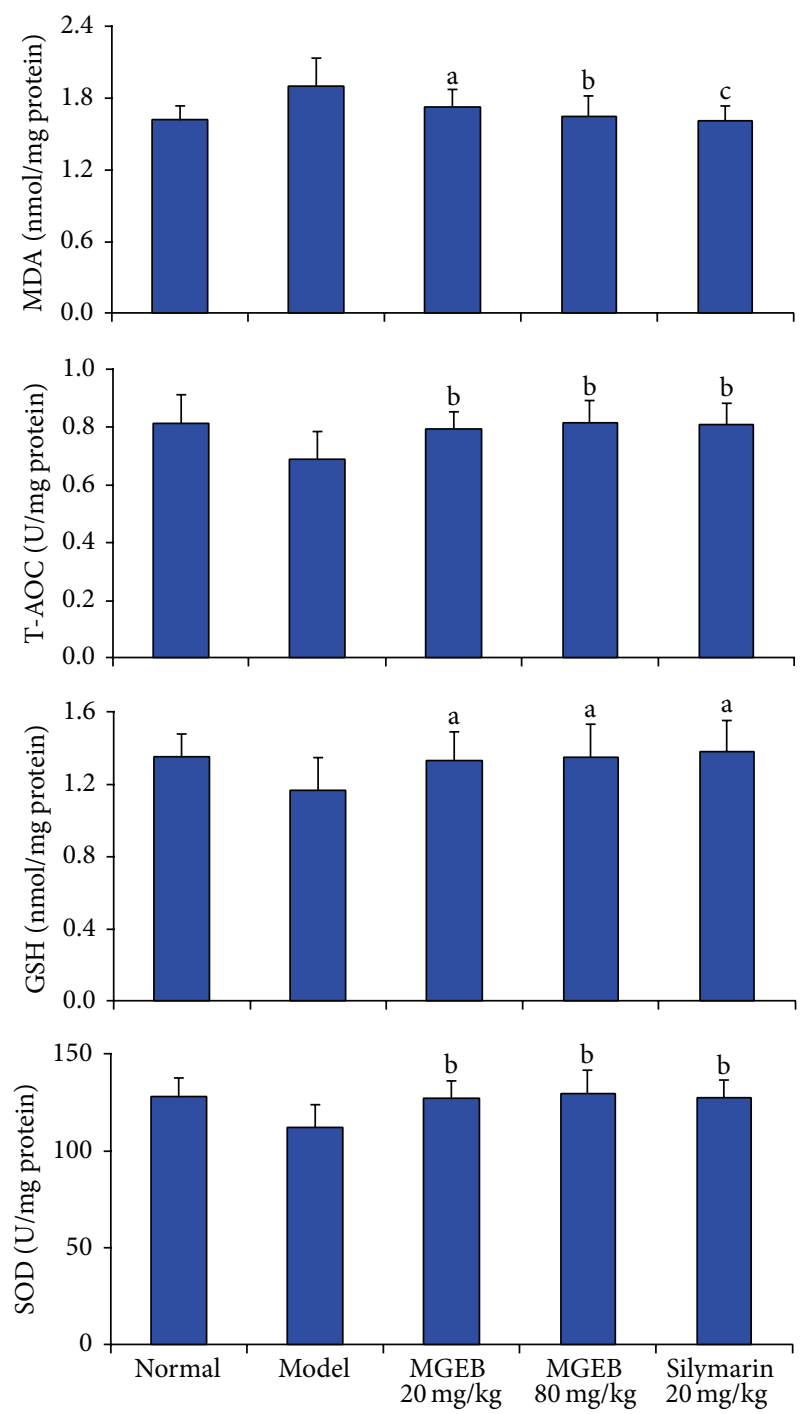

FIGURE 4: MGEB protect against $\mathrm{CCl}_{4}$ induced oxidative stress in liver of mice. The data were expressed as mean \pm standard deviation $(n=10)$; significant differences with model group were designated as ${ }^{\mathrm{a}} P<0.05,{ }^{\mathrm{b}} P<0.01$, and ${ }^{\mathrm{c}} P<0.001$.

16.5 Hz, H-4 $\alpha), 2.37(1 \mathrm{H}, \mathrm{dd}, J=3.0,16.5 \mathrm{~Hz}, \mathrm{H}-4 \beta) .{ }^{13} \mathrm{C} \mathrm{NMR}$ $\left(125 \mathrm{MHz}, \mathrm{DMSO}-d_{6}\right): \delta 156.46(\mathrm{C}-7), 156.18(\mathrm{C}-5), 155.71(\mathrm{C}-$ 8a), $146.33\left(\mathrm{C}-3^{\prime}, 5^{\prime}\right), 132.09\left(\mathrm{C}-4^{\prime}\right), 129.69\left(\mathrm{C}-1^{\prime}\right), 106.03\left(\mathrm{C}-2^{\prime}\right.$, $\left.6^{\prime}\right), 98.54$ (C-4a), 95.03 (C-6), 94.05 (C-8), 78.09 (C-2), 64.96 (C-3), 28.09 (C-4).

3.6.5. Catechin $(4 \alpha \rightarrow 8)$ Catechin (5). ESI-MS gave an [M$\mathrm{H}]^{-}$at $m / z$ : 577.8. ${ }^{1} \mathrm{H}$ NMR (500 MHz, DMSO- $\left.d_{6}\right)$ : Upper (catechin) unit: $\delta 6.84\left(1 \mathrm{H}, \mathrm{d}, J=2.0 \mathrm{~Hz}, \mathrm{H}-2^{\prime}\right), 6.76(1 \mathrm{H}, \mathrm{dd}$, $\left.J=8.0,2.0 \mathrm{~Hz}, \mathrm{H}-6^{\prime}\right), 6.70\left(1 \mathrm{H}, \mathrm{d}, J=8.0 \mathrm{~Hz}, \mathrm{H}-5^{\prime}\right), 5.67(1 \mathrm{H}$, d, $J=2.5 \mathrm{~Hz}, \mathrm{H}-8), 5.61(1 \mathrm{H}, \mathrm{d}, J=2.5 \mathrm{~Hz}, \mathrm{H}-6), 4.26(1 \mathrm{H}, \mathrm{d}, J$ $=7.5 \mathrm{~Hz}, \mathrm{H}-4), 4.21$ (1H, m, H-3), $4.17(1 \mathrm{H}, \mathrm{d}, J=9.5 \mathrm{~Hz}, \mathrm{H}-2)$. Lower (catechin) unit: $\delta 6.82\left(1 \mathrm{H}, \mathrm{d}, J=2.0 \mathrm{~Hz}, \mathrm{H}-2^{\prime}\right), 6.65$ $\left(1 \mathrm{H}, \mathrm{dd}, J=8.0,2.0 \mathrm{~Hz}, \mathrm{H}-6^{\prime}\right), 6.58\left(1 \mathrm{H}, \mathrm{d}, J=8.0 \mathrm{~Hz}, \mathrm{H}-5^{\prime}\right)$, $5.85(1 \mathrm{H}, \mathrm{s}, \mathrm{H}-6), 4.72(1 \mathrm{H}, \mathrm{d}, J=7.5 \mathrm{~Hz}, \mathrm{H}-2), 3.86(1 \mathrm{H}, \mathrm{m}$, $\mathrm{H}-3), 2.81(1 \mathrm{H}, \mathrm{dd}, J=16.5,6.0 \mathrm{~Hz}, \mathrm{H}-4 \alpha), 2.41(1 \mathrm{H}, \mathrm{dd}, J=$ 16.5, $8.5 \mathrm{~Hz}, \mathrm{H}-4 \beta) .{ }^{13} \mathrm{C}$ NMR (125 MHz, DMSO- $d_{6}$ ): Upper (catechin) unit: $\delta 154.53(\mathrm{C}-7), 153.48$ (C-5), 153.29 (C-8a), $144.83\left(\mathrm{C}-3^{\prime}\right), 144.68\left(\mathrm{C}-4^{\prime}\right), 130.81\left(\mathrm{C}-1^{\prime}\right), 119.39\left(\mathrm{C}-6^{\prime}\right), 115.15$ $\left(\mathrm{C}-5^{\prime}\right), 114.79\left(\mathrm{C}-2^{\prime}\right), 106.16$ (C-4a), 95.93 (C-8), 94.14 (C-6), 82.51 (C-2), 71.05 (C-3), 37.29 (C-4). Lower (catechin) unit: $\delta$ 157.34 (C-7), 155.99 (C-5), 155.50 (C-8a), $144.72\left(\mathrm{C}-3^{\prime}\right), 144.56$ $\left(\mathrm{C}-4^{\prime}\right), 130.96\left(\mathrm{C}-1^{\prime}\right), 118.80\left(\mathrm{C}-6^{\prime}\right), 115.20\left(\mathrm{C}-5^{\prime}\right), 114.92(\mathrm{C}-$ $2^{\prime}$ ), 108.40 (C-8), 98.95 (C-4a), 95.89 (C-6), 81.42 (C-2), 66.68 (C-3), $29.49(\mathrm{C}-4)$.

3.6.6. Gallocatechin $(4 \alpha \rightarrow 8)$ Gallocatechin (6). ESI-MS gave an $[\mathrm{M}-\mathrm{H}]^{-}$at $m / z: 609.8 .{ }^{1} \mathrm{H}$ NMR $\left(500 \mathrm{MHz}, \mathrm{DMSO}-d_{6}\right)$ : Upper (gallocatechin) unit: $\delta 6.57\left(1 \mathrm{H}, \mathrm{s}, \mathrm{H}-2^{\prime}\right), 6.57(1 \mathrm{H}, \mathrm{s}$, $\left.\mathrm{H}-6^{\prime}\right), 5.89(1 \mathrm{H}, \mathrm{d}, J=2.5 \mathrm{~Hz}, \mathrm{H}-8), 5.85(1 \mathrm{H}, \mathrm{d}, J=2.5 \mathrm{~Hz}$, H-6), $4.56(1 \mathrm{H}, \mathrm{d}, J=8.0 \mathrm{~Hz}, \mathrm{H}-4), 4.44(1 \mathrm{H}, \mathrm{d}, J=8.0 \mathrm{~Hz}, \mathrm{H}-$ 3), $4.23(1 \mathrm{H}, \mathrm{d}, J=9.5 \mathrm{~Hz}, \mathrm{H}-2)$. Lower (gallocatechin) unit: $\delta 6.58\left(1 \mathrm{H}, \mathrm{s}, \mathrm{H}-2^{\prime}\right), 6.58\left(1 \mathrm{H}, \mathrm{s}, \mathrm{H}-6^{\prime}\right), 6.04(1 \mathrm{H}, \mathrm{s}, \mathrm{H}-6), 4.67$ $(1 \mathrm{H}, \mathrm{d}, J=7.0 \mathrm{~Hz}, \mathrm{H}-2), 4.11(1 \mathrm{H}, \mathrm{d}, J=6.5 \mathrm{~Hz} \mathrm{H}-3), 2.79(1 \mathrm{H}$, dd, $J=16.0,6.0 \mathrm{~Hz}, \mathrm{H}-4 \alpha), 2.40(1 \mathrm{H}, \mathrm{dd}, J=16.5,8.5 \mathrm{~Hz}, \mathrm{H}-$ $4 \beta) .{ }^{13} \mathrm{C}$ NMR (125 MHz, DMSO- $\left.d_{6}\right)$ : Upper (gallocatechin) unit: $\delta 157.33$ (C-7), 155.98 (C-5), 155.51 (C-8a), $145.42\left(\mathrm{C}-3^{\prime}\right.$, C-5 $\left.5^{\prime}\right), 132.54\left(\mathrm{C}-4^{\prime}\right), 130.05\left(\mathrm{C}-1^{\prime}\right), 107.00\left(\mathrm{C}-2^{\prime}, \mathrm{C}-6^{\prime}\right), 106.09$ (C-4a), 95.88 (C-8), 94.11 (C-6), 82.76 (C-2), 71.03 (C-3), 37.07 (C-4). Lower (gallocatechin) unit: $\delta 154.57$ (C-7), $153.47(\mathrm{C}-$ 5), 153.32 (C-8a), $145.42\left(\mathrm{C}-3^{\prime}, \mathrm{C}-5^{\prime}\right), 132.54\left(\mathrm{C}-4^{\prime}\right), 129.87$ (C$\left.1^{\prime}\right), 108.35$ (C-8), $106.74\left(\mathrm{C}-2^{\prime}, \mathrm{C}-6^{\prime}\right), 99.00$ (C-4a), 95.88 (C6), 81.78 (C-2), 66.65 (C-3), 29.47 (C-4).

3.6.7. Gallocatechin ( $4 \alpha \rightarrow 8)$ Epigallocatechin (7). ESI-MS gave an $[\mathrm{M}-\mathrm{H}]^{-}$at $\mathrm{m} / z$ : 609.8. ${ }^{1} \mathrm{H}$ NMR $(500 \mathrm{MHz}$, DMSO$\left.d_{6}\right)$ : Upper (gallocatechin) unit: $\delta 6.59\left(1 \mathrm{H}, \mathrm{s}, \mathrm{H}-2^{\prime}, \mathrm{H}-6^{\prime}\right)$, $5.88(1 \mathrm{H}, \mathrm{d}, J=2.5 \mathrm{~Hz}, \mathrm{H}-8), 5.86(1 \mathrm{H}, \mathrm{d}, J=2.5 \mathrm{~Hz}, \mathrm{H}-6), 4.68$ $(1 \mathrm{H}, \mathrm{d}, J=7.5 \mathrm{~Hz}, \mathrm{H}-4), 4.51(1 \mathrm{H}, \mathrm{d}, J=8.0 \mathrm{~Hz}, \mathrm{H}-3), 4.38(1 \mathrm{H}$, $\mathrm{d}, J=9.5 \mathrm{~Hz}, \mathrm{H}-2)$. Lower (epigallocatechin) unit: $\delta 6.71(1 \mathrm{H}$, s, H-2' H-6 $\left.^{\prime}\right), 6.04$ (1H, s, H-6), $4.93(1 \mathrm{H}, \mathrm{d}, J=9.5 \mathrm{~Hz}, \mathrm{H}-2)$, 4.25 (1H, br s, H-3), 2.83 (1H, dd, $J=17.0,2.5 \mathrm{~Hz}, \mathrm{H}-4 \alpha), 2.74$ $(1 \mathrm{H}, \mathrm{dd}, J=16.5,8.5 \mathrm{~Hz}, \mathrm{H}-4 \beta) .{ }^{13} \mathrm{C}$ NMR $(125 \mathrm{MHz}$, DMSO$\left.d_{6}\right)$ : Upper (gallocatechin) unit: $\delta 157.34$ (C-7), $156.00(\mathrm{C}-5)$, 155.51 (C-8a), 145.42 (C-3', C-5'), $132.54\left(\mathrm{C}-4^{\prime}\right), 129.97\left(\mathrm{C}-1^{\prime}\right)$, 107.04 (C-2' $\left.{ }^{\prime}, \mathrm{C}^{\prime} 6^{\prime}\right), 106.05$ (C-4a), 95.91 (C-8), 94.15 (C-6), 82.53 (C-2), 71.24 (C-3), 37.24 (C-4). Lower (epigallocatechin) unit: $\delta 154.63(\mathrm{C}-7), 153.84(\mathrm{C}-5), 153.46$ (C-8a), 145.29 (C-3', C-5 $\left.5^{\prime}\right), 132.05\left(\mathrm{C}-4^{\prime}\right), 130.11\left(\mathrm{C}-1^{\prime}\right), 108.24(\mathrm{C}-8), 106.16\left(\mathrm{C}-2^{\prime}\right.$, C-6' $)$, 97. 91 (C-4a), 95.77 (C-6), 78.39 (C-2), 65.14 (C-3), 29.18 (C-4).

3.6.8. Gallocatechin $(4 \alpha \rightarrow 8)$ Catechin (8). ESI-MS gave an $[\mathrm{M}-\mathrm{H}]^{-}$at $m / z: 593.9 .{ }^{1} \mathrm{H} \mathrm{NMR}\left(500 \mathrm{MHz}, \mathrm{DMSO}-d_{6}\right):$ Upper (gallocatechin) unit: $\delta 6.57\left(1 \mathrm{H}, \mathrm{s}, \mathrm{H}-2^{\prime}, \mathrm{H}-6^{\prime}\right), 5.95(1 \mathrm{H}, \mathrm{d}, J$ $=2.0 \mathrm{~Hz}, \mathrm{H}-8), 5.80(1 \mathrm{H}, \mathrm{d}, J=2.5 \mathrm{~Hz}, \mathrm{H}-6), 4.65(1 \mathrm{H}, \mathrm{d}, J$ $=7.0 \mathrm{~Hz}, \mathrm{H}-4), 4.54(1 \mathrm{H}, \mathrm{d}, J=9.0 \mathrm{~Hz}, \mathrm{H}-3), 4.38(1 \mathrm{H}, \mathrm{d}, J=$ $9.5 \mathrm{~Hz}, \mathrm{H}-2)$. Lower (catechin) unit: $\delta 7.03\left(1 \mathrm{H}, \mathrm{s}, \mathrm{H}-2^{\prime}\right), 6.90$ $\left(1 \mathrm{H}, \mathrm{dd}, J=8.5,2.0 \mathrm{~Hz}, \mathrm{H}-6^{\prime}\right), 6.79\left(1 \mathrm{H}, \mathrm{d}, J=8.0 \mathrm{~Hz}, \mathrm{H}-5^{\prime}\right)$, $6.05(1 \mathrm{H}, \mathrm{s}, \mathrm{H}-6), 4.75(1 \mathrm{H}, \mathrm{d}, J=7.5 \mathrm{~Hz}, \mathrm{H}-2), 4.09(1 \mathrm{H}, \mathrm{m}$, $\mathrm{H}-3), 2.92(1 \mathrm{H}, \mathrm{dd}, J=16.5,5.5 \mathrm{~Hz}, \mathrm{H}-4 \alpha), 2.65(1 \mathrm{H}, \mathrm{dd}, J=$ 16.5, 8.5 Hz, H-4 $\beta) .{ }^{13} \mathrm{C}$ NMR (125 MHz, DMSO- $\left.d_{6}\right)$ : Upper (gallocatechin) unit: $\delta 157.34(\mathrm{C}-7), 155.98$ (C-5), $155.49(\mathrm{C}-$ $8 \mathrm{a}), 145.40\left(\mathrm{C}-3^{\prime}, \mathrm{C}-5^{\prime}\right), 132.54\left(\mathrm{C}-4^{\prime}\right), 130.04\left(\mathrm{C}-1^{\prime}\right), 107.04(\mathrm{C}-$ $\left.2^{\prime}, \mathrm{C}^{\prime} 6^{\prime}\right), 106.13$ (C-4a), 95.89 (C-8), 94.13 (C-6), 82.80 (C-2), 
<smiles>Oc1cc(O)c2c(c1)O[C@H](c1ccc(O)c(O)c1)[C@H](O)C2</smiles>

1<smiles>Oc1cc(O)c2c(c1)O[C@H](c1ccc(O)c(O)c1)[C@H](O)[C@H]2c1c(O)cc(O)c2c1O[C@H](c1ccc(O)c(O)c1)[C@H](O)C2</smiles>

5<smiles>Oc1cc(O)c2c(c1)O[C@H](c1cc(O)c(O)c(O)c1)[C@H](O)[C@H]2c1c(O)cc(O)c2c1O[C@H](c1ccc(O)c(O)c1)[C@H](O)C2</smiles>

8<smiles>Oc1cc(O)c2c(c1)O[C@H](c1cc(O)c(O)c(O)c1)[C@H](O)C2</smiles>

3<smiles>Oc1cc(O)c2c(c1)O[C@H](c1cc(O)c(O)c(O)c1)[C@H](O)C2</smiles><smiles>Oc1cc(O)c2c(c1)O[C@H](c1cc(O)c(O)c(O)c1)[C@H](O)[C@H]2c1c(O)cc(O)c2c1O[C@H](c1cc(O)c(O)c(O)c1)[C@H](O)C2</smiles>

6<smiles>Oc1cc(O)c2c(c1)O[C@H](c1ccc(O)c(O)c1)[C@H](O)[C@H]2c1c(O)cc(O)c2c1O[C@H](c1cc(O)c(O)c(O)c1)[C@H](O)C2</smiles>

9<smiles>Oc1cc(O)c2c(c1)O[C@H](c1cc(O)c(O)c(O)c1)[C@H](O)[C@H]2c1c(O)cc(O)c2c1O[C@H](c1cc(O)c(O)c(O)c1)[C@H](O)C2</smiles>

7<smiles>Oc1cc(O)c2c(c1)O[C@H](c1cc(O)c(O)c(O)c1)[C@H](O)[C@H]2c1c(O)cc(O)c2c1O[C@H](c1ccc(O)c(O)c1)[C@H](O)C2</smiles>

10

Figure 5: Proanthocyanidins from the bark of M. glyptostroboides.

71.06 (C-3), 37.09 (C-4). Lower (catechin) unit: $\delta 154.52$ (C-7), 153.48 (C-5), 153.28 (C-8a), $144.71\left(\mathrm{C}-3^{\prime}\right), 144.56\left(\mathrm{C}-4^{\prime}\right), 130.81$ $\left(\mathrm{C}-1^{\prime}\right), 118.80\left(\mathrm{C}-6^{\prime}\right), 115.12\left(\mathrm{C}-5^{\prime}\right), 114.93\left(\mathrm{C}-2^{\prime}\right), 108.41(\mathrm{C}-8)$, 98.95 (C-4a), 95.89 (C-6), 81.42 (C-2), 66.70 (C-3), 29.47 (C4).

3.6.9. Catechin $(4 \alpha \rightarrow 8)$ Gallocatechin (9). ESI-MS gave an $[\mathrm{M}-\mathrm{H}]^{-}$at $m / z: 593.9 .{ }^{1} \mathrm{H} \mathrm{NMR}\left(500 \mathrm{MHz}, \mathrm{DMSO}-d_{6}\right)$ : Upper (catechin) unit: $\delta 7.01\left(1 \mathrm{H}, \mathrm{s}, \mathrm{H}-2^{\prime}\right), 6.86(1 \mathrm{H}, \mathrm{dd}, J=8.0$, $\left.2.0 \mathrm{~Hz}, \mathrm{H}-6^{\prime}\right), 6.82\left(1 \mathrm{H}, \mathrm{d}, J=8.0 \mathrm{~Hz}, \mathrm{H}-5^{\prime}\right), 5.87(1 \mathrm{H}, \mathrm{s}, \mathrm{H}-$ 8), $5.86(1 \mathrm{H}, \mathrm{s}, \mathrm{H}-6), 4.45(1 \mathrm{H}, \mathrm{d}, J=7.5 \mathrm{~Hz}, \mathrm{H}-4), 4.41(1 \mathrm{H}$, $\mathrm{dd}, J=9.5,7.5 \mathrm{~Hz}, \mathrm{H}-3), 4.27(1 \mathrm{H}, \mathrm{d}, J=9.5 \mathrm{~Hz}, \mathrm{H}-2)$. Lower (gallocatechin) unit: $\delta 6.58\left(1 \mathrm{H}, \mathrm{s}, \mathrm{H}-2^{\prime}, \mathrm{H}-6^{\prime}\right), 6.05(1 \mathrm{H}, \mathrm{s}$, H-6), 4.66 (1H, d, $J=7.5 \mathrm{~Hz}, \mathrm{H}-2), 4.08$ (1H, m, H-3), 2.92 $(1 \mathrm{H}, \mathrm{dd}, J=16.0,5.5 \mathrm{~Hz}, \mathrm{H}-4 \alpha), 2.64(1 \mathrm{H}, \mathrm{dd}, J=16.5,8.5 \mathrm{~Hz}$, $\mathrm{H}-4 \beta) .{ }^{13} \mathrm{C}$ NMR $\left(125 \mathrm{MHz}, \mathrm{DMSO}-d_{6}\right)$ : Upper (catechin) unit: $\delta 154.59(\mathrm{C}-7), 153.48(\mathrm{C}-5), 153.32(\mathrm{C}-8 \mathrm{a}), 144.84\left(\mathrm{C}-3^{\prime}\right)$, $144.68\left(\mathrm{C}-4^{\prime}\right), 129.86\left(\mathrm{C}-1^{\prime}\right), 119.37\left(\mathrm{C}-6^{\prime}\right), 115.17\left(\mathrm{C}-5^{\prime}\right), 114.80$ $\left(\mathrm{C}-2^{\prime}\right), 106.10$ (C-4a), 94.92 (C-8), 94.13 (C-6), 82.48 (C-2), 71.01 (C-3), 37.21 (C-4). Lower (gallocatechin) unit: $\delta 157.31$ (C-7), 155.99 (C-5), 155.51 (C-8a), 145.42 (C-3', C-5'), 132.55 $\left(\mathrm{C}-4^{\prime}\right), 130.95\left(\mathrm{C}-1^{\prime}\right), 108.33(\mathrm{C}-8), 106.76\left(\mathrm{C}-2^{\prime}, \mathrm{C}-6^{\prime}\right), 99.01$ (C-4a), 95.92 (C-6), 81.78 (C-2), 66.63 (C-3), 29.48 (C-4).
3.7. Gallocatechin $(4 \alpha \rightarrow 8)$ Epicatechin (10). ESI-MS gave an $[\mathrm{M}-\mathrm{H}]^{-}$at $m / z$ : 593.9. ${ }^{1} \mathrm{H}$ NMR $\left(500 \mathrm{MHz}, \mathrm{DMSO}-d_{6}\right)$ : Upper (gallocatechin) unit: $\delta 6.49\left(1 \mathrm{H}, \mathrm{s}, \mathrm{H}-2^{\prime}, \mathrm{H}-6^{\prime}\right), 5.85$ $(1 \mathrm{H}, \mathrm{d}, J=2.0 \mathrm{~Hz}, \mathrm{H}-8), 5.67(1 \mathrm{H}, \mathrm{d}, J=2.5 \mathrm{~Hz}, \mathrm{H}-6), 4.48$ $(1 \mathrm{H}, \mathrm{d}, J=7.0 \mathrm{~Hz}, \mathrm{H}-4), 4.41(1 \mathrm{H}, \mathrm{d}, J=9.0 \mathrm{~Hz}, \mathrm{H}-3), 4.25$ $(1 \mathrm{H}, \mathrm{d}, J=9.5 \mathrm{~Hz}, \mathrm{H}-2)$. Lower (epicatechin) unit: $\delta 6.97(1 \mathrm{H}$, s, H-2 $\left.{ }^{\prime}\right), 6.83\left(1 \mathrm{H}, \mathrm{dd}, J=8.5,2.0 \mathrm{~Hz}, \mathrm{H}-6^{\prime}\right), 6.67(1 \mathrm{H}, \mathrm{d}, J$ $\left.=8.0 \mathrm{~Hz}, \mathrm{H}-5^{\prime}\right), 5.86(1 \mathrm{H}, \mathrm{s}, \mathrm{H}-6), 4.73(1 \mathrm{H}$, br s, H-2), 4.11 $(1 \mathrm{H}, \mathrm{m}, \mathrm{H}-3), 2.92(1 \mathrm{H}, \mathrm{dd}, J=16.5,4.5 \mathrm{~Hz}, \mathrm{H}-4 \alpha), 2.53(1 \mathrm{H}$, $\mathrm{dd}, J=16.5,2.5 \mathrm{~Hz}, \mathrm{H}-4 \beta) .{ }^{13} \mathrm{C}$ NMR $\left(125 \mathrm{MHz}, \mathrm{DMSO}-d_{6}\right)$ : Upper (gallocatechin) unit: $\delta 155.98(\mathrm{C}-7), 155.51(\mathrm{C}-5), 155.50$ (C-8a), $145.41\left(\mathrm{C}-3^{\prime},{\mathrm{C}-5^{\prime}}^{\prime}\right), 132.53\left(\mathrm{C}-4^{\prime}\right), 131.02\left(\mathrm{C}-1^{\prime}\right), 107.06$ (C-4a), 106.17 (C-2' , C-6'), 95.91 (C-6), 94.18 (C-8), 82.55 (C2), 71.27 (C-3), 37.27 (C-4). Lower (epicatechin) unit: $\delta 157.38$ (C-7), 157.33 (C-5), 156.01 (C-8a), $144.68\left(\mathrm{C}-3^{\prime}\right), 144.84\left(\mathrm{C}-4^{\prime}\right)$, $132.06\left(\mathrm{C}-1^{\prime}\right), 119.38\left({\mathrm{C}-6^{\prime}}^{\prime}\right), 115.22\left(\mathrm{C}-5^{\prime}\right), 114.74\left(\mathrm{C}-2^{\prime}\right), 108.23$ (C-8), 97.91 (C-4a), 95.95 (C-6), 78.40 (C-2), 65.12 (C-3), 29.20 (C-4).

\section{Discussion}

It has been recognized that the free radical scavenging capacity and antioxidant activity of majority plant extracts 
are associated with their phenolic, flavonoid, or proanthocyanidin contents [28-30]. To obtain effective free radical scavenging and antioxidant materials from the bark of $M$. glyptostroboides, in present study, gradient water-ethanol (water, $60 \%$ or $95 \%$ ethanol) were first used as an extraction solvent to get the crude extracts, and the contents of total phenolic, flavonoid, and proanthocyanidin in each extract were determined. As shown in Table 1, among all three extracts, although the 95\% ethanol extract (MGE95) had the highest contents of total phenolics and proanthocyanidins, the $60 \%$ ethanol extract (MGE60) obtained the highest extraction yield. The yields of total phenolics, flavonoids, and proanthocyanidins were higher in $60 \%$ ethanol extract (MGE60) than those in 95\% ethanol extract (MGE95). Subsequently, the $60 \%$ ethanol extract (MGE60) was selected for further study.

In this study, the $60 \%$ ethanol extract was then subjected to D101 resin column chromatography and eluted with a water-ethanol step gradient to afford three fractions, MGEA (water fraction), MGEB (30\% ethanol fraction), and MGEC (50\% ethanol fraction). As shown in Table 1, the total phenolic, flavonoid, and proanthocyanidin contents in MGEB were significantly higher than those of its parent extracts and other two fractions, and its yield was also higher than that of other two fractions. These data suggest that resin column chromatography is suitable for enrichment of the phenolics, flavonoids, and proanthocyanidins from extracts of the bark of M. glyptostroboides.

DPPH is a nitrogen-centered stable free radical, and their color changes from violet to yellow when it is reduced by the process of either hydrogen or electron donation. Among the oxygen radicals, hydroxyl radical is the most reactive in biological systems and has been implicated as a highly damaging species in free radical pathology, which is capable of damaging almost every molecule found in living cells. This radical has the capacity to join nucleotides in DNA and cause strand breakage which contributes to carcinogenesis, mutagenesis, and cytotoxicity [2]. Superoxide anion is a weak oxidant; however, it plays important roles in the formation of powerful and dangerous ROS such as hydrogen peroxide, hydroxyl radical, and singlet oxygen, which induce oxidative damage in lipids, proteins, and DNA [29, 31]. Therefore, these three free radicals were used for comparison of the free radical scavenging capacity of the extracts and fractions from the bark of M. glyptostroboides. As shown in Figure 1, all the extracts and fractions seem to be good scavengers of free radicals, and MGEB possessed strongest capacity.

Lipid peroxidation in biological systems has long been thought to be a toxicological phenomenon that can lead to various pathological consequences. $\mathrm{Fe}^{2+}$-ascorbic acid mixture is well known to stimulate lipid peroxidation in rat liver in vivo and in microsome and mitochondria of rat liver in vitro. Metal chelating capacity is an important antioxidant property since it reduced the concentration of the catalysing transition metal in lipid peroxidation. $\mathrm{Fe}^{2+}$ is the most powerful prooxidant among the various species of catalysing transition metal ions [2]. To better characterize the antioxidant potentials, in this study, the extracts and fractions from the bark of $M$. glyptostroboides were assessed for the $\mathrm{T}-\mathrm{AOC}$, the lipid peroxidation inhibitory activity, and $\mathrm{Fe}^{2+}$ chelating activity. Consistent with the findings in free radical scavenging capacity, all the extracts and fractions exhibited a significant antioxidant activity, and MGEB possessed the strongest capacity (Figure 2).

Previously, we and others have reported that extracts or compounds with chelating activity are believed to inhibit lipid peroxidation by stabilizing transition metals chelating agents $[2,32]$. However, in this study, the $\mathrm{IC}_{50}$ values of all the extracts and fractions except the fraction MGEA in $\mathrm{Fe}^{2+}$ chelating activity were much higher than those in lipid peroxidation inhibitory activity. These results means that although these extracts and fractions possess marked capacities for iron binding, their lipid peroxidation inhibitory activity may not be directly related to the iron binding capacity.

To further evaluate the antioxidant activity of the bark of M. glyptostroboides in vivo, the effect of $\mathrm{MGEB}$ on $\mathrm{CCl}_{4}$ induced oxidative stress was assessed. $\mathrm{CCl}_{4}$ is metabolized by hepatic microsomal cytochrome (CYP)2E1, CYP2B1, or CYP2B2 to form a reactive trichloromethyl $\left(\mathrm{CCl}_{3}^{\circ}\right)$ radical. This radical can bind to cellular molecules (nucleic acid, protein, and lipid), impairing crucial cellular processes such as lipid metabolism, damage antioxidant enzymes such as SOD, and depletion on the levels of GSH which have a key role in coordinating innate antioxidant defense mechanisms and eventually leading to lipid peroxidation, cell necrosis, and the leakage of the marker enzymes such as AST and ALT into serum $[33,34]$. In this study, pretreatment with MGEB significantly attenuated $\mathrm{CCl}_{4}$-induced liver damage in mice, evidenced by decreased serum enzyme activities of ALT and AST, which was also supported by the histopathological examination of the mice liver (Figure 3). MGEB also showed a significant protective effect against $\mathrm{CCl}_{4}$ induced hepatic MDA elevation and depletion of T-AOC, SOD, and GSH content (Figure 4). These findings indicated that MGEB has potent free radical scavenging and antioxidant activities both in vitro and in vivo.

Proanthocyanidins are polymeric flavan-3-ols which can serve as electron donor to terminate the radical chain reaction. Their antioxidant activity is dependant not only on the concentration, but also on the structure of individual compounds (such as the number of phenolic hydroxyl groups and their position), the degree of polymerization, and the interaction between the antioxidants [30]. As strong antioxidant, Pycnogenol is utilized for various diseases. Between $65 \%$ and $75 \%$ of Pycnogenol is proanthocyanidins, mainly comprising of catechin and epicatechin subunits with varying chain lengths [8]. The relationship analysis between free radical scavenging, antioxidant activities, and the content of total phenolics, flavonoids, and proanthocyanidins (Table 2) showed that proanthocyanidin compounds were major contributors to the free radical scavenging capacity and antioxidant activity of the extracts and fractions from the bark of $M$. glyptostroboides. To identify the active compounds, MGEB, which possessed the highest proanthocyanidins content and the highest free radical scavenging and antioxidant activities, 
was subjected to Sephadex LH-20 column chromatograph. The proanthocyanidins in M. glyptostroboides contain not only catechin and epicatechin, but also gallocatechin and epigallocatechin subunits (Figure 5), which are highly heterogeneous from Pycnogenol. It is reported that gallocatechins with a $3^{\prime}, 4^{\prime}, 5^{\prime}$-trihydroxyphenyl B-ring are more efficient free radical scavengers than catechins [28]. This may be the reason why several extracts and fractions such as MGEB and MGE95 are with lower total proanthocyanidin content, but exhibited stronger free radical scavenging capacity and antioxidant activity than Pycnogenol.

\section{Conclusion}

As far as we know, this study is the first to report the free radical scavenging capacity, antioxidant activity, and proanthocyanidin composition of the bark of M. glyptostroboides. From the present findings, it was concluded that the extracts and fractions from the bark of M. glyptostroboides have DPPH radical, superoxide anion radical, and hydroxyl radical scavenging capacity, ferric reducing ability, lipid peroxidation inhibitory activity, and metal ions chelating capacity. It also provided evidence that these activities were mainly related to their proanthocyanidin content. In addition, the data indicated that the fraction MGEB, which was obtained by $60 \%$ ethanol extraction and further separation with D101 resin column chromatograph, possessed the highest proanthocyanidin content and the strongest free radical scavenging and antioxidant activities. Furthermore, MGEB could significantly protect against $\mathrm{CCl}_{4}$ induced acute liver injury via control of oxidative stress in vivo. In addition, ten proanthocyanidins were isolated from MGEB, and six of them are firstly reported from this plant. Taken together, these findings would be beneficial for developing and utilizing the bark of M. glyptostroboides. It also suggested the potential of the proanthocyanidins-enriched fraction as low-cost antioxidant for use in the treatment of various oxidative stress-related diseases.

\section{Conflict of Interests}

The authors declare that there is no conflict of interests.

\section{Acknowledgments}

The work was supported by Zhejiang Provincial Program for the Cultivation of High-level Innovative Health talents, Zhejiang Provincial Medicinal Health Program (2012KYA051), Zhejiang Provincial Science and Technology Council (2011F20013, 2013F10005), and Medical Key Subject of Zhejiang Province (XKQ-010-001).

\section{References}

[1] J. D. Lambeth, "Nox enzymes, ROS, and chronic disease: an example of antagonistic pleiotropy," Free Radical Biology and Medicine, vol. 43, no. 3, pp. 332-347, 2007.
[2] S.-F. Xu, Y.-P. Ye, X.-Y. Li, and F.-Y. Chen, "Chemical composition and antioxidant activities of different polysaccharides from the roots of Angelica dahurica," Chemistry and Biodiversity, vol. 8, no. 6, pp. 1121-1131, 2011.

[3] G. Vázquez, E. Fontenla, J. Santos, M. S. Freire, J. GonzálezÁlvarez, and G. Antorrena, "Antioxidant activity and phenolic content of chestnut (Castanea sativa) shell and eucalyptus (Eucalyptus globulus) bark extracts," Industrial Crops and Products, vol. 28, no. 3, pp. 279-285, 2008.

[4] G. Vázquez, J. González-Alvarez, J. Santos, M. S. Freire, and G. Antorrena, "Evaluation of potential applications for chestnut (Castanea sativa) shell and eucalyptus (Eucalyptus globulus) bark extracts," Industrial Crops and Products, vol. 29, no. 2-3, pp. 364-370, 2009.

[5] N. Roy, R. A. Laskar, I. Sk, D. Kumari, T. Ghosh, and N. A. Begum, "A detailed study on the antioxidant activity of the stem bark of Dalbergia sissoo Roxb., an Indian medicinal plant," Food Chemistry, vol. 126, no. 3, pp. 1115-1121, 2011.

[6] D. Kremer, I. Kosalec, M. Locatelli et al., "Anthraquinone profiles, antioxidant and antimicrobial properties of Frangula rupestris (Scop.) Schur and Frangula alnus Mill. bark," Food Chemistry, vol. 131, no. 4, pp. 1174-1180, 2012.

[7] S. A. O. Santos, J. J. Villaverde, C. S. R. Freire, R. M. M. Domingues, C. P. Neto, and A. J. D. Silvestre, "Phenolic composition and antioxidant activity of Eucalyptus grandis, E. urograndis (E. grandis $\times$ E. urophylla) and E. maidenii bark extracts," Industrial Crops and Products, vol. 39, pp. 120-127, 2012.

[8] G. D’Andrea, "Pycnogenol: a blend of procyanidins with multifaceted therapeutic applications?" Fitoterapia, vol. 81, no. 7, pp. 724-736, 2010.

[9] J. Ma, "The chronology of the "living fossil" Metasequoia glyptostroboides (taxodiaceae): a review (1943-2003)," Harvard Papers in Botany, vol. 8, no. 1, pp. 9-18, 2003.

[10] V. K. Bajpai, A. Rahman, and S. C. Kang, "Chemical composition and anti-fungal properties of the essential oil and crude extracts of Metasequoia glyptostroboides Miki ex Hu," Industrial Crops and Products, vol. 26, no. 1, pp. 28-35, 2007.

[11] V. K. Bajpai, S. M. Al-Reza, U. K. Choi, J. H. Lee, and S. C. Kang, "Chemical composition, antibacterial and antioxidant activities of leaf essential oil and extracts of Metasequioa glyptostroboides Miki ex Hu," Food and Chemical Toxicology, vol. 47, no. 8, pp. 1876-1883, 2009.

[12] L.-B. Dong, J. He, Y.-Y. Wang et al., "Terpenoids and norlignans from Metasequoia glyptostroboides," Journal of Natural Products, vol. 74, no. 2, pp. 234-239, 2011.

[13] Q. Zeng, X.-R. Cheng, J.-J. Qin et al., "Norlignans and phenylpropanoids from Metasequoia glyptostroboides Hu et Cheng," Helvetica Chimica Acta, vol. 95, no. 4, pp. 606-612, 2012.

[14] Q. Zeng, B. Guan, X. R. Cheng et al., "Chemical constituents from Metasequoia glyptostroboides Hu et Cheng," Biochemical Systematics and Ecology, vol. 50, pp. 406-410, 2013.

[15] F. Wang, E.-X. Yu, and W.-W. Liu, "Protective effects of total flavones of metasequosia on cerebral ischemia-reperfusion injury in rats," Zhongguo Zhong Yao Za Zhi, vol. 29, no. 2, pp. 179-181, 2004.

[16] L. Y. Foo, Y. Lu, W. C. McNabb, G. Waghorn, and M. J. Ulyatt, "Proanthocyanidins from Lotus pedunculatus," Phytochemistry, vol. 45, no. 8, pp. 1689-1696, 1997.

[17] L. Y. Foo, Y. Lu, A. L. Molan, D. R. Woodfield, and W. C. McNabb, "The phenols and prodelphinidins of white clover flowers," Phytochemistry, vol. 54, no. 5, pp. 539-548, 2000. 
[18] O. N. Ozo, J. C. Caygill, and D. G. Coursey, "Phenolics of five yam (dioscorea) species," Phytochemistry, vol. 23, no. 2, pp. 329331, 1984.

[19] M. Tits, L. Angenot, P. Poukens, R. Warin, and Y. Dierckxsens, "Prodelphinidins from Ribes nigrum," Phytochemistry, vol. 31, no. 3, pp. 971-973, 1992.

[20] F. Hashimoto, G. I. Nonaka, and I. Nishioka, "Tanins and related comounds LXXVII: novel chalcan-flavan dimers, Assamicains $\mathrm{A}, \mathrm{B}$ and $\mathrm{C}$, and a new flavan-3-ol and proanthocyanidins from the fresh leaves of Camellia sinensis L. Var. Assamica KITAMURA," Chemical and Pharmaceutical Bulletin, vol. 37, no. 1, pp. 77-85, 1989.

[21] R. K. Gupta and E. Haslam, "Plant proanthocyanidins. Part 7. Prodelphinidins from Pinus sylvestris," Journal of the Chemical Society, Perkin Transactions 1, pp. 1148-1150, 1981.

[22] W.-G. Quan, B.-X. Yu, J.-Y. Zhang et al., "A facile approach to synthesis of the di-O-methyl ethers of (-)-agatharesinol, (-)-sugiresinol, (+)-nyasol and (+)-tetrahydronyasol," Chinese Journal of Chemistry, vol. 25, no. 5, pp. 688-693, 2007.

[23] L. J. Porter, L. N. Hrstich, and B. G. Chan, "The conversion of procyanidins and prodelphinidins to cyanidin and delphinidin," Phytochemistry, vol. 25, no. 1, pp. 223-230, 1985.

[24] T. Yokozawa, C. P. Chen, E. Dong, T. Tanaka, G.-I. Nonaka, and I. Nishioka, "Study on the inhibitory effect of tannins and flavonoids against the 1,1-diphenyl-2-picrylhydrazyl radical," Biochemical Pharmacology, vol. 56, no. 2, pp. 213-222, 1998.

[25] L. Li, Y. Zhang, P. Zhang, H. Pi, H. Ruan, and J. Wu, "Appraisal of anti-inflammatory and free radical scavenging activities of ethanol extract of Ilex ficoidea Hemsl and Ilex centrochinensis S.Y. Hu," Environmental Toxicology and Pharmacology, vol. 32, no. 2, pp. 122-127, 2011.

[26] I. F. F. Benzie and J. J. Strain, "The ferric reducing ability of plasma (FRAP) as a measure of "antioxidant power": the FRAP assay," Analytical Biochemistry, vol. 239, no. 1, pp. 70-76, 1996.

[27] X. Liu, M. Zhao, J. Wang, B. Yang, and Y. Jiang, "Antioxidant activity of methanolic extract of emblica fruit (Phyllanthus emblica L.) from six regions in China," Journal of Food Composition and Analysis, vol. 21, no. 3, pp. 219-228, 2008.

[28] C. A. Rice-Evans, N. J. Miller, and G. Paganga, "Structure-antioxidant activity relationships of flavonoids and phenolic acids," Free Radical Biology and Medicine, vol. 20, no. 7, pp. 933-956, 1996.

[29] P.-G. Pietta, "Flavonoids as antioxidants," Journal of Natural Products, vol. 63, no. 7, pp. 1035-1042, 2000.

[30] C. Santos-Buelga and A. Scalbert, "Proanthocyanidins and tannin-like compounds-nature, occurrence, dietary intake and effects on nutrition and health," Journal of the Science of Food and Agriculture, vol. 80, no. 7, pp. 1094-1117, 2000.

[31] A. P. Wickens, "Ageing and the free radical theory," Respiration Physiology, vol. 128, no. 3, pp. 379-391, 2001.

[32] I. Gülçin, Z. Huyut, M. Elmastaş, and H. Y. Aboul-Enein, "Radical scavenging and antioxidant activity of tannic acid," Arabian Journal of Chemistry, vol. 3, no. 1, pp. 43-53, 2010.

[33] L. W. D. Weber, M. Boll, and A. Stampfl, "Hepatotoxicity and mechanism of action of haloalkanes: carbon tetrachloride as a toxicological model," Critical Reviews in Toxicology, vol. 33, no. 2, pp. 105-136, 2003.

[34] G. Kaur, M. S. Alam, Z. Jabbar, K. Javed, and M. Athar, "Evaluation of antioxidant activity of Cassia siamea flowers," Journal of Ethnopharmacology, vol. 108, no. 3, pp. 340-348, 2006. 


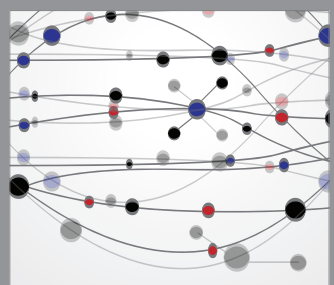

The Scientific World Journal
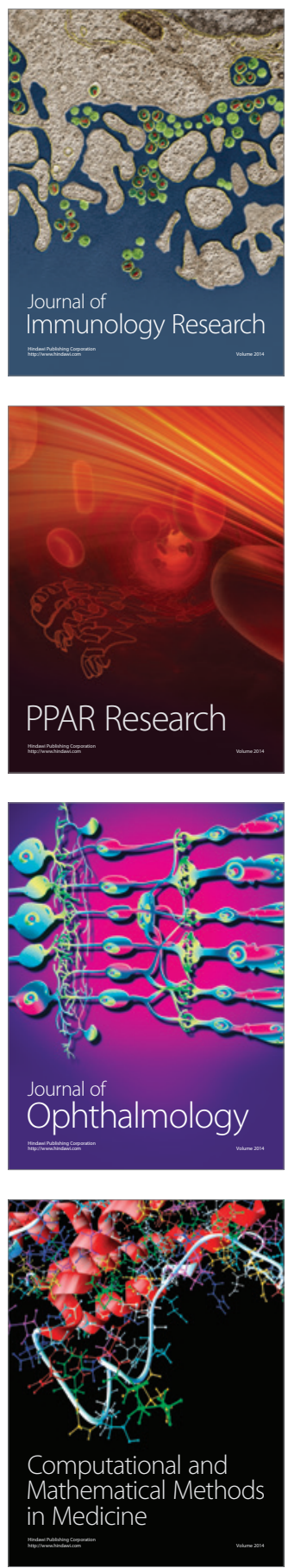

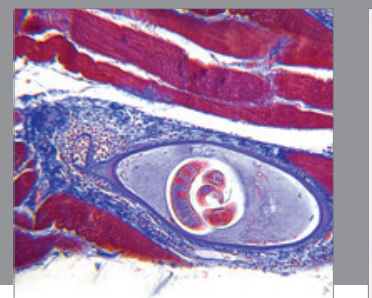

Gastroenterology

Research and Practice
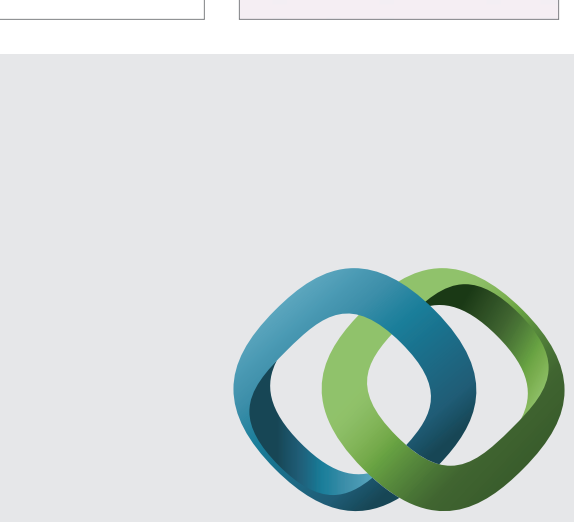

\section{Hindawi}

Submit your manuscripts at

http://www.hindawi.com
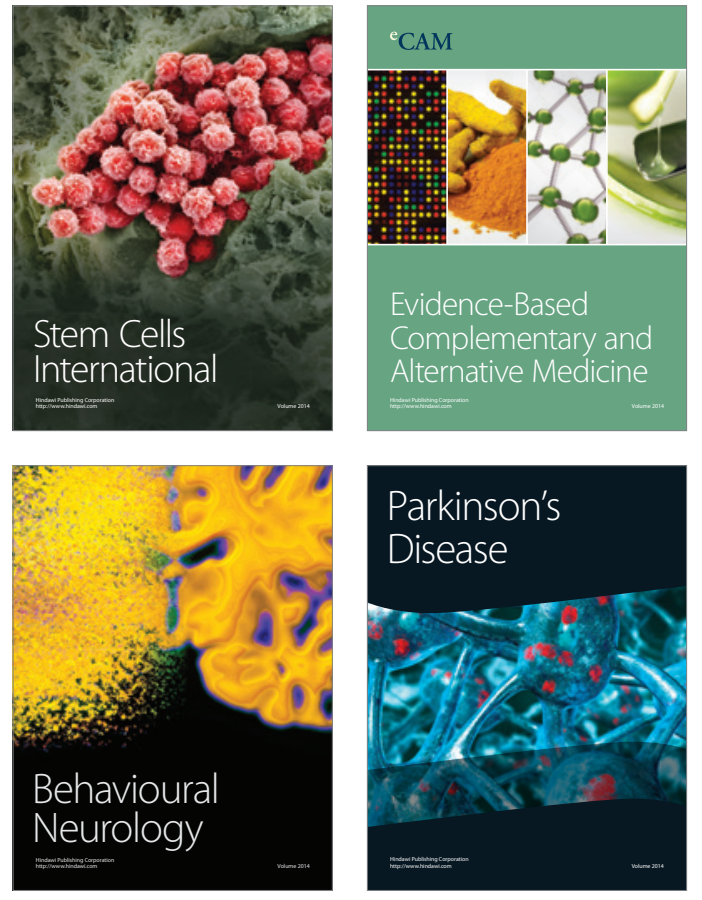
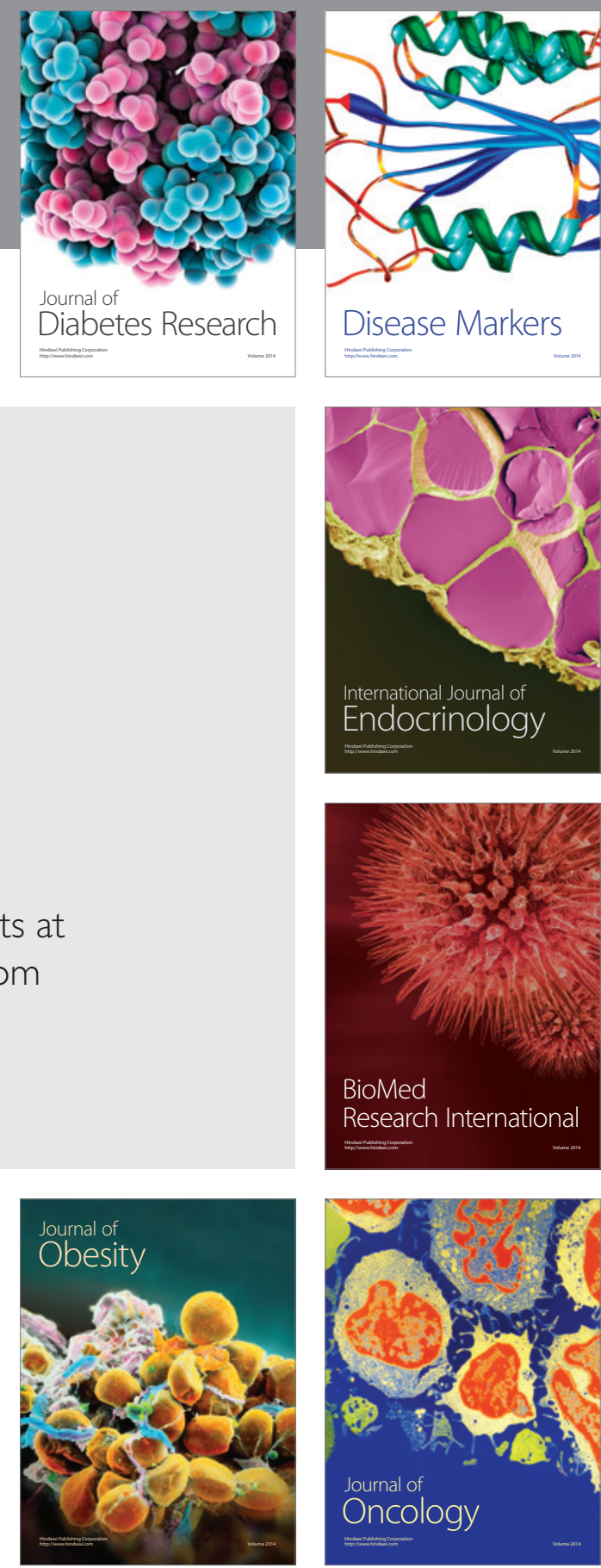

Disease Markers
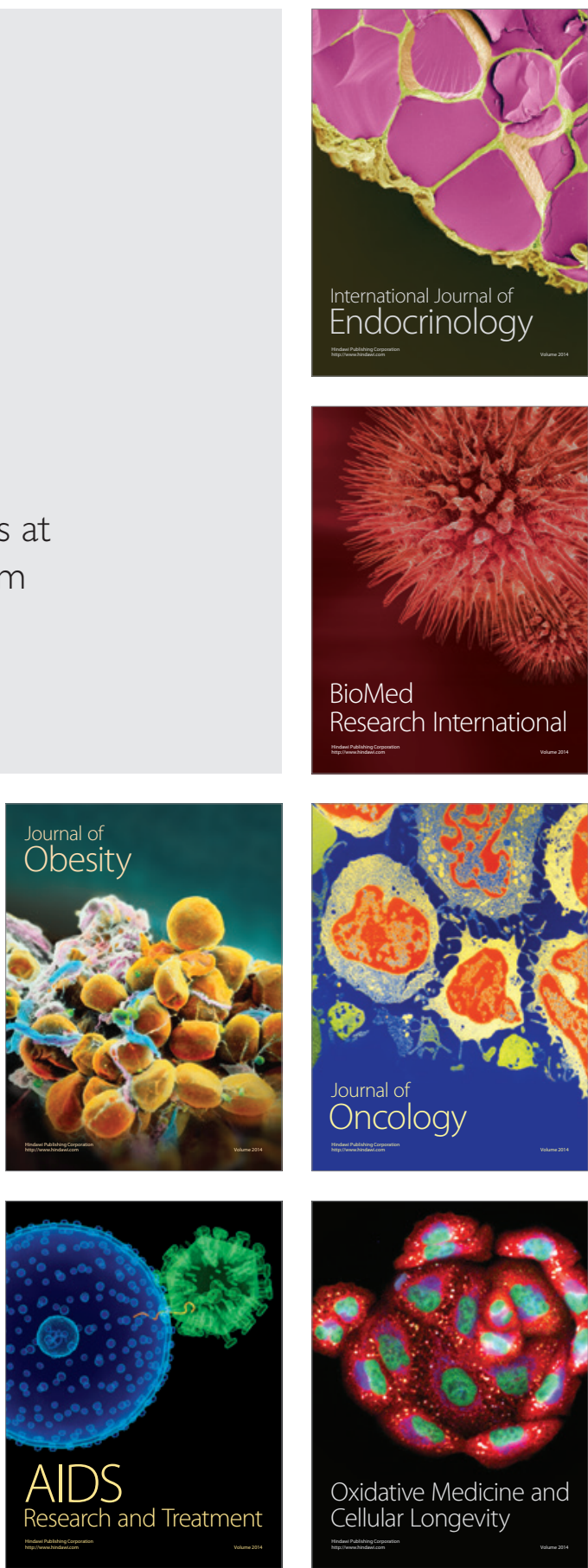